\title{
NÁRODNÍ IDENTITA V MUZEU V CENTRU VÝZKUMNÉ POZORNOSTI: PŘEHLEDOVÁ STUDIE

\section{VERONIKA KOLAŘÍKOVÁ}

\section{ABSTRAKT/ABSTRACT}

Cílem předkládané přehledové studie je seznámit čtenáře s pojetím výzkumu národní identity v prostředí muzeí. Za tímto účelem text nejprve diskutuje pojem národní identity a zprostř̌edkovává základní vhled do tohoto tématu. Dále se text zabývá problematikou proměny výzkumného paradigmatu $\mathrm{v}$ muzeích a ukazuje, že dřívější výzkumný zájem o demografické charakteristiky muzejních návštěvníků byl posléze nahrazen zájmem o návštěvníkovu osobní zkušenost. Důraz z kvantitativního výzkumu se tak postupně přesunul na výzkum kvalitativní nebo smíšené povahy, což se projevilo i v rámci zkoumání národní identity. Samotný výzkum národní identity prezentované muzei je nakonec představen prostřednictvím analýzy tří vybraných výzkumných studií, které demonstrují nejen metodologické uchopení výzkumu národní identity v muzeu, ale prezentují také zajímavá a podnětná zjištění.

\section{National identity in museums in the focal point of research interest: synoptic study}

The aim of this study is to acquaint the reader with the concept of research into national identity in museums. For this purpose, the text first discusses the concept of national identity and provides a basic insight into this topic. Furthermore the text deals with the transformation of the research paradigm in museums and shows that previous research interest in the demographic characteristics of museum visitors was later replaced by a focus on the visitor's personal experience. The emphasis that has been placed on quantitative research has gradually shifted to research of qualitative or mixed character, which was also reflected in the studies of national identity. The research into national identity presented by museums is finally exemplified through the analysis of three selected research studies which not only demonstrate the methodological concept of research into national identity in museums, but also present interesting and stimulating findings.

\section{KLÍČOVÁ SLOVA/ KEYWORDS}

národní identita - muzeum - přehledová studie - výzkum - konstruktivistické teorie učení - národní muzeum national identity - museum - review - research - constructivist theories of learning - national museums

Národní identita je jednou z nejdůležitějších složek lidské identity. Zájem o ni je tak v současné době $\mathrm{v}$ centru pozornosti sociologie, psychologie, pedagogiky, antropologie a neuniká z dohledu ani muzejní pedagogice, muzeologii, jakožto i dalším vědním disciplínám. Pro muzejní výzkum je přitom národní identita významnou proměnnou, nebot koncept národní identity je na prostředí muzeí úzce navázán. Spojitost má především s muzei národními, které se s otázkou národní identity každodenně vypořádávají a podílejí se nejen na prezentaci, ale také na konstrukci její podoby.

Cílem přehledové studie je na základě analýzy tří vybraných výzkumných studií ukázat, jak může v současnosti probíhat výzkum národní identity v muzeích za cílem demonstrovat, jak s tématem národní identity konkrétní výzkumy pracují (tj. co je v rámci výzkumu národní identity zajímá a $\mathrm{k}$ jakým závěrům dospívají) a jakou metodologii používají k jeho zkoumání. Cílem textu přitom není poskytnout vyčerpávající přehled všech výzkumných studií na toto téma, nýbrž seznámit čtenáře s tématem a důležitostí výzkumu národní identity $\mathrm{v}$ muzeích jako takovým a poskytnout komplexnější vhled do této ne př́liš často diskutované problematiky.

Za tímto účelem bude v textu nejprve představen koncept národní identity, který se bude odvíjet od diskuze jeho základních prvků, jimiž jsou pojmy národ a identita. Následně se pozornost přesune k muzejnímu výzkumnému paradigmatu s užším zaměřením na problematiku výzkumu publika. Popsán bude jeho historický vývoj a proměna a to ve snaze nabídnout vhled do stavu vědeckého zkoumání publika v prostředí muzeí. Publikum je totiž vedle muzejních sbírek, potažmo celých expozic a jejich tvůrců další základní složkou celého procesu konstrukce národní identity v prostředí muzeí. Hlubší pozornost pak bude zaměřena na význam muzeí $\mathrm{v}$ procesu prezentace a konstrukce národní identity. $S$ tímto cílem budou prezentovány tři vybrané výzkumné studie, které se právě výzkumu národní identity v prostředí muzea věnovaly. Představena bude nejen jejich metodologie, ale také zajímavá zjišsění, která výzkumy přinesly. 


\section{NÁRODNÍ IDENTITA}

Pojem národní identity je dnes nejen často diskutovaným a užívaným pojmem, ale jde také o pojem komplikovaný a složitý. Lavi ${ }^{1}$ pojem národní identity v kontextu dnešní doby označuje přímo za matoucí fenomén. Mnozí autoři totiž pracují s tímto pojmem různě a často se tak setkáváme s jeho obsahovou nejednotností a růzností. I to je fakt, který by si výzkumníci měli na začátku své výzkumné práce uvědomit a v rámci výzkumu národní identity $\mathrm{v}$ muzeu proto nejprve definovat, co pod pojmem národní identity sami rozumějí a jak s tímto pojmem hodlají ve svém výzkumu pracovat.

Národní identita je pojem složený ze dvou základních konceptů - národ a identita. Pojmy národa se dnes obvykle orientují na definování národa prostřednictvím společné kultury, reprezentované především jazykem, dějinami a tradicemi. Spolu s tím bývá národ chápán jako sdílené politické společenství, tj. (národní) stát. Přrináležitost $\mathrm{k}$ národu přitom může být dána objektivně, tj. prostřednictvím totožné kultury a obývaného území, ale také subjektivně, což znamená vědomím prŕíslušnosti k danému národu. ${ }^{2}$ Jed-

\footnotetext{
1 LAVI, Liron. Making Time for National Identity: Theoretical Concept and Empirical Glance on the Temporal Performance of National Identity. Nations and Nationalism, 2013, roč. 19, č. 4, s. 696.

2 Srov. MAŘíKOVÁ, Hana, Miroslav PETRUSEK a Alena VODÁKOVÁ et al. Velký sociologický slovník. Praha: Karolinum, 1996; JANDOUREK, Jan. Sociologický slovník. Praha: Portál, 2001. Předkládané slovníkové definice národa jsou $\mathrm{v}$ tuto chvíli vhodným zdrojem $\mathrm{k}$ objasnění tohoto pojmu. Odrážejí totiž jeho současné paradigmální pojetí. Současně se snaží postihnout všechny jeho prvky, díky čemuž umožňují zobecnit tento pojem a poskytnout jasný vhled do jeho problematiky. Definice zrcadlí základní povědomí lidí o významu pojmu národ i jeho vědecké chápání, avšak nejsou plně vyčerpávající. Je to dáno nejen rozsahem, který je ve slovnících omezen, ale především tím, že mnozí autoři dnes stále píší o národu různě a opírají se v jeho definicích o různé národotvorné prvky. Některé definice využívají kritéria společného jazyka, u jiných autorů jsou zase definice národa opřeny o společný etnický základ, kulturní rysy, dějiny či společné území. Slovníkové definice upozorňují na všechny tyto roviny pojmu národa a národnosti a předkládají
}

notlivé definice národa pak využívají těchto objektivních a subjektivních prvků národnosti $v$ různé míře dle konkrétního pojetí autora, který o nich píše. Ve výsledku tak lze pozorovat, že jednotlivé definice, které v odborné literatuře nalezneme, sice zrcadlí základní povědomí lidí o významu pojmu národ, avšak nejsou plně vyčerpávající. Nelze ani očekávat, že všechny definice národa, se kterými autoři pracují, bývají univerzálně platné. $\mathrm{V}$ rámci objektivních definic národa totiž dle Hobsbawma ${ }^{3}$ bude vždy možné najít určité výjimky, které stanoveným národnostním kritériím (jakými jsou společný jazyk, společný etnický základ, kulturní rysy, dějiny či společné území apod.) nevyhovují a navíc ani samotná „národní“ kritéria nejsou jednoznačná a statická. Národy, včetně jejich definic, proto nelze zařadit do univerzálního systému. Konkrétní objektivní definice národa není nikdy zcela definitivně možnou.

Příkladem toho, jak mohou jednotliví autoři klást dưraz na rozdílné prvky národní identity, jsou definice primordialistické, které byly užívané spíše v minulosti. Primordialisté charakterizují národ jako odvěkou a přirozenou kategorii zakládající se převážně na etnických rysech jakými jsou jazyk a kultura. ${ }^{4}$ Národ pojímají jako odjakživa existující realitu, jako esencializující základní stavební kámen lidstva. Proti tomuto chápání národa se vymezuje Gellner, ${ }^{5}$ známý sociolog nacionalismu a představitel konstruktivistického pojetí národa, který říká, že národ „není vrozená všeobecná vlastnost lidstva, ale stalo se nyní, že to tak

\footnotetext{
tak jakýsi ideální typ, který nabízí ucelený vhled do problematiky tohoto pojmu.

3 HOBSBAWM, Erik J. Národy a nacionalismus od roku 1780: program, mýtus, realita. Brno: Centrum pro studium demokracie a kultury, 2000, s. 10. 4 Srov. HROCH, Miroslav. Národy nejsou dílem náhody. Praha: Sociologické nakladatelství, 2009; GELLNER, Ernest. Nacionalismus. Brno: Centrum pro studium demokracie a kultury, 2003.

5 GELLNER, Arnošt. Národy a nacionalismus. Praha: Hříbal, 1993, s. 17.
}

vypadá. Ve skutečnosti národy, stejně jako státy, jsou nahodilostí a nikoli všeobecnou nutností. Ani národy ani státy neexistují ve všech dobách a za v̌sech okolností."

Uvědomění si přináležitosti k národu je pro moderního člověka poměrně samozřejmou zkušeností, $\mathrm{v}$ minulosti tomu tak ale nebylo. Lidé nad svou národností v tradičních dobách neuvažovali, kategorizace lidí skrze pojem národa nebyla automatická. Aby se kategorie národa jakožto klasifikační nástroj mohla stát každodenní součástí reality a vnímání lidí, musely nastat specifické podmínky (ty se dle Gellnera pojí s procesem modernizace $\left.{ }^{6}\right)$, které umožnily a vyžádaly si započetí existence národa a jeho vnímání jako samozřejmého a přirozeného, přičemž samotná tato kategorie odvěká a nevyhnutelná není. Současné koncepce národa si tento fakt často uvědomují, a proto dle Hrocha ${ }^{7}$ kladou větší důraz na subjektivní a vědomý pocit přináležitosti $\mathrm{k}$ národu. To se odráží i v definici národa, o kterém lze dle Hrocha ${ }^{8}$,hovoriit tehdy, kdy se s národem ztotožňují všichni, nebo téměr všichni, kdo př́cházejí v úvahu jako jeho možní př́slušníci.“

\footnotetext{
6 Dle Gellnera (srov. GELLNER, Arnošt. Národy a nacionalismus. Praha: Hříbal, 1993; GELLNER, Ernest. Pluh, meč a kniha: struktura lidských dějin. Brno: Centrum pro studium demokracie a kultury, 2001; GELLNER, Ernest. Nacionalismus. Brno: Centrum pro studium demokracie a kultury, 2003.) struktury, jež se proměnily s nástupem mo dernity, a které sehrály základní roli při procesu formování se a rozvíjení se nacionalismu a s ním souvisejícího důrazu, jenž začal být kladen na národní identity, souvisejí především s procesem industrializace. Spolu s modernizací a industrializací v tomto procesu sehrála velkou úlohu moderní vize nekončícího pokroku, s níž souvisela neustálá změna (technologická, společenská apod.) a mobilita (vertikální i horizontální); sémantická povaha práce a pro modernu specifická dělba práce; univerzální gramotnost daná všeobecným vzděláním a jednotná všeobjímající vysoká kultura; byrokratizace a rozvoj moderní formy komunikace; stát a jeho vnímání jako danosti a přirozenosti; rozvoj občanské společnosti a rozšiřování se společenské rovnosti.

7 HROCH, Miroslav. Národy nejsou dílem náhody. Praha: Sociologické nakladatelství, 2009.

8 HROCH, Miroslav. Národy nejsou dílem náhody. Praha: Sociologické nakladatelství, 2009, s. 53.
} 
Druhým základním konceptem národní identity je pojem identita, kterou můžeme chápat jako „hluboký pocit vlastní totožnosti založený na prožívání vlastní komunity. "9 Identita v sobě obsahuje jedincovi hodnoty, světonázor, životní role, prožitek příslušnosti ke společenskému celku. Můžeme tak hovořit o osobních a kolektivních identitách, přičemž kolektivní identita je charakterizována jako „společná shoda členů o podstatných rysech skupiny, o tom, kdo k ní patři a kdo nikoli, a co by skupina měla a co by neměla dělat." ${ }^{10}$ Národní identitu pak lze dle Careyho ${ }^{11}$ chápat právě jako kolektivní sociální identitu, která se projevuje jako pozitivní vztah jedince $\mathrm{k}$ vlastnímu národu a zemi a jako pocit příslušnosti $\mathrm{k}$ danému národu, s nímž se pojí vymezení se vůči národům a kulturám jiným. Nevyhnutelně se tak národní identita vztahuje $\mathrm{k}$ představě vlastní skupiny „my“, která je odlišovaná od skupin cizích a odlišných, tzv. „oni“. Běžně se tak můžeme setkat $s$ rozlišováním náš versus cizí národ, naše versus cizí zvyky, naše versus jejich národní povaha apod.

Národní identita je tedy skupinovou identitou, která je běžným fenoménem moderní doby a zakládá se na řadě charakteristik, jakými jsou společná kultura, jazyk, dějiny a svrchovaný stát. I přes různé nadnárodní tendence a transformace vnímá Lavi ${ }^{12}$ národní identitu stále jako základ pro tvorbu kolektivního sebeurčení a identitu prezentuje jako průběžně a stále konstruovanou skrze neustále opakované každodenní jednání, rituály i mluvení

\footnotetext{
9 JANDOUREK, Jan. Sociologický slovník. Praha: Portál, 2001, s. 104.

10 JANDOUREK, Jan. Sociologický slovník. Praha: Portál, 2001 s. 104.

11 CAREY, Sean. Undivided Loyalties. Is National Identity an Obstacle to European Integration? European Union Politics, 2002, roč. 3, č. 4, s. $387-413$.

12 LAVI, Liron. Making Time for National Identity: Theoretical Concept and Empirical Glance on the Temporal Performance of National Identity. Nations and Nationalism. 2013, roč. 19, č. 4 , s. $696-714$.
}

o národě a jeho reprezentaci s cílem dosáhnout pocitu sounáležitosti a identifikace jedince s tímto národem a s ním pojící se identitou. Obdobně i Smith ${ }^{\mathbf{1 3}}$ chápe národní identitu jako součást sebepojetí (národní) komunity. Národní identitu přitom podle něj nelze vnímat jen jako pouhou variantu skupinové identity, nebot' „do jejího utváření vstupuje také osobní identita a identita sociální, které vyjadřují, jak se jedinec prezentuje $v$ sociální interakci a jak jej $v$ interakci prijímají ostatní." ${ }^{14}$ Funkcí národní identity pak je to, že definuje příslušnost člověka ke kolektivní osobnosti a určuje tak jeho místo ve světě.

\section{NÁRODNÍ IDENTITA A MUZEUM}

Mnohá muzea jsou s národní identitou neoddělitelně spjatá, o čemž svědčí už samotná pozice národních muzeí. Ta byla s národní identitou spojeny především v době svého vzniku a následného rozmachu v 19. století, v němž se v muzejní činnosti výrazně odráží právě národotvorná funkce orientovaná na podporu národního cítění, prezentace národní historie a s ní spojené národní hrdosti. ${ }^{15}$

Národní identita je ale důležitou součástí i dnešních (nejen) národních muzeí. Dle Anelle van Wyk ${ }^{\mathbf{1 6}}$ jsou muzea rituálními místy, která se podílejí na utváření národní identity svých návštěvníků. K její konstrukci dochází tím, že muzea

\footnotetext{
13 SMITH, Anthony D. National identity and vernacular mobilisation in Europe. Nations and Nationalism. 2011, roč. 17, č. 2, s. 223-256. 14 HROCH, Miroslav. Národy nejsou dílem náhody. Praha: Sociologické nakladatelství, 2009, s. 38.

15 JAGOŠOVÁ, Lucie, Vladimír JŮVA a Lenka MRÁZOVÁ. Muzejní pedagogika: metodologické a didaktické aspekty muzejní edukace. Brno: Paido, 2010.

16 VAN WYK, Anelle. The Unreconciled Ritual: Identity and Politics at the Museum [online]. Netherlands: Humanity in Action, 2000 [cit. 2014-02-12]. Dostupné z www: ‘http://www. humanityinaction.org/knowledgebase/302-the-unreconciled-ritual-identity-and-politics-at-themuseum
}

předkládají návštěvníkům objekty pojící se $\mathrm{k}$ minulosti (ve snaze propojit minulost se současností) a reprezentují skupinu jako takovou (včetně skupinových hodnot, ideálů a „pravd“), díky čemuž zde mohou lidé svou národní identitu objevovat. Svými pečlivě navrženými expozicemi a s nimi pojícími se příběhy podněcují muzea návštěvníky $\mathrm{k}$ účasti a souhlasu a skrze jejich přijetí návštěvnické role je zapojují do muzejního rituálu. Stejně jako i jiné rituály se pak i muzea podílejí na vytváření a inscenaci hodnot a přesvědčení o společenských, politických, občanských, kolektivních, morálních, náboženské, sexuálních a národních identitách. Muzea přitom mohou zprostředkovávat identitu vlastní, ale i cizí skupiny. Reprezentace sebe samých a cizích jsou zde propojeny, nebot sebe můžeme definovat právě skrze odlišení se od jiných. Kategorizace skupin i identit, jakožto i jejich konstrukce je proto nevyhnutelnou součástí muzejního prostředí.

Van Wyk ${ }^{17}$ zaujímá k prostředí muzea poměrně kritický postoj, když říká, že zde často dochází k (cílenému) budování nacionalistické iluze (např. skrze prezentování mýtů, protínání minulosti s budoucností apod.). Muzea jsou mocenskými prostory, které dle autorky rámují objekty a manipulují situace a příběhy, jež mohou deklarovat jako relevantní nebo důležité poznatky, mohou $\mathrm{k}$ nim poutat pozornost i konstruovat jejich význam, stejně tak je mohou ale i ničit a zakrývat. Tím mohou ovlivňovat příběhy, které prezentují svým návštěvníkům a skrze ně se mohou pokoušet formovat jejich postoje. Muzea tak lze vnímat jako motory ideologie i snahy o politický vliv. Muzea jako místa obdařená určitou mocí

\footnotetext{
17 VAN WYK, Anelle. The Unreconciled Ritual: Identity and Politics at the Museum [online]. Netherlands: Humanity in Action, 2000 [cit. 2014-02-12]. Dostupné z www: ${ }^{<}$http://www. humanityinaction.org/knowledgebase/302-the-unreconciled-ritual-identity-and-politics-at-themuseum ${ }^{2}$
} 
předkládat a manipulovat určité společenské příběhy vnímá i Kreuzzieger, ${ }^{18}$ podle něhož je muzeum „místem koncentrace vědění, [muzeum] formuje a prezentuje ,naše pojetí světa, nabízí hodnotovou a estetickou klasifikaci, činí viditelné narativní struktury vědění, které legitimizují mocenskou hierarchii, a pomocí těchto mechanismů je i místem kontroly a moci.“

Tvrzení obou autorů bychom mohli zařadit mezi tzv. kritické teorie muzea, které se soustředí na uvědomění si spjatosti muzea s mocí a ideologií, s jeho schopností konstruovat společenskou realitu a její obraz existující v myslích sociálních aktérů, kteří se následně vlastním jednáním na konstrukci sociální reality podílejí. Tyto teorie obvykle upozorňují na fakt, že přestože se muzea tváŕí jako objektivní místa, tak „muzejní reprezentace se svou snahou o pravdivé a objektivní zobrazení světa ve skutečnosti objektivitu postrádá a je ovlivněna mnoha nepřiznanými a skrytými okolnostmi. Jak uvádí D. Preziosi: muzea stanovila, co je hodno vidění, a zároveň uči své návštěvníky, jak čist to, co vidí." ${ }^{19}$ Skrze kritické teorie muzea je pak muzejní prostředí „nazíráno kriticky, a to $v$ nejrůznějších historických, společenských, ideologických, ale i ekonomických vztazích. Autoři studií odhalují, že muzeum není nestrannou, objektivní institucí, která prezentuje neměnnou Pravdu, nýbrž že je produktem své vlastní doby a v mnoha svých rysech se projevuje jako mocenská, totalitní instituce, která konstruuje své teze $v$ závislosti na společenských požadavcích či vládnoucí ideologii." ${ }^{20}$

\footnotetext{
18 KREUZZIEGER, Milan. Flexibilní identita a projekt kosmopolitního muzea. Politologická revue, 2008, č. 1, s. 93.

19 ŠOBÁŇOVÁ, Petra. Muzejní expozice jako edukační médium 1. díl: Př́stupy k tvorbě expozic a jejich inovace. Olomouc: Univerzita Palackého v Olomouci, 2014, s. 99.

20 ŠOBÁŇOVÁ, Petra. Kritické teorie muzea podnět k reflexi. Muzeum: Muzejní a vlastivědná práce, 2012, roč. 50, č. 2, s. 27.
}

Jako takové pak mohou být kritické teorie muzea součástí či nástrojem kritické muzeologie, která upozorňuje právě na to, že jsou muzea a jejich expozice produkty společnosti a doby, v níž vznikly. Jsou proto ovlivněny nejrůznějšími sociálními, politickými i ekonomickými kontexty, v rámci kterých sami existují. Následně pak mohou muzea a jejich příběhy ovlivňovat podobu znalostí, které konstruují a prezentují svým návštěvníkům. Dle kritické muzeologie je nutné vnímat tyto prezentace jako odrážející konkrétní situace a podmínky existence muzea a tedy i jako omezené reprezentace předkládaných jevů. Tato neúplnost předkládaných informací může nastat nahodile, ale i cíleně, kdy se dle kritické muzeologie muzea mohou snažit (respektive se viditelně především v minulosti snažila) o to budovat národní či regionální identitu a to skrze přivlastnění si historie a prezentace historické paměti, která se může podílet na budování kolektivní hrdosti a celkové (sebe) identifikaci a to pod záštitou objektivity a neutrality předkládaných faktů. Ty přitom dle kritické muzeologie často neutrální a objektivní nejsou, nýbrž jsou podmíněny nejen sociálními kontexty, ale také politickými cíli či přesvědčeními, přáními a hodnotami zaangažovaných osob. $^{21}$

Na druhou stranu bychom měli zohlednit ale i další faktory podílející se na návštěvníkově $v$ muzeu nabyté zkušenosti, znalosti, osvojených postojích apod. V potaz je dobré vzít především konstruktivistické teorie učení, které jsou pro oblast muzeí poměrně klíčové. Konstruktivistické teorie učení dle Heina, ${ }^{22}$ který úzce navazuje především na dílo Deweyho, vycházejí z teorie

\footnotetext{
21 NAVARRO, Oscar. History and education as base for museum legitimacy in latin american museums: some comments for a discussion from a critical muzeology point of view. Museologica Brunensia, 2012, roč. 1, č. 1, s. $28-33$.

22 HEIN, George E. Is Meaning Making Constructivism? Is Constructivism Meaning Making? The Exhibitionist, 1999, roč. 18, č. 2, s. 15-18.
}

konstruktivismu a pedagogiky, a jsou teoriemi, které zdůrazňují aktivní participaci učícího se jedince na procesu učení, resp. na procesu získávání znalostí, dovedností, budování hodnot a postojů apod. $\mathrm{Z}$ pohledu těchto teorií se proces porozumění zakládá na aktivní konstrukci znalostí samotným učícím se jedincem, at už žákem, nebo návštěvníkem muzea. Poznávající jedinec interpretuje předkládaná data tak, aby mu dávala smysl, což je proces založený nejen na jeho schopnostech a dovednostech, ale i dosavadních znalostech a zkušenostech, které jsou sociálně a kulturně determinované. Nelze proto předpokládat, že $\mathrm{v}$ rámci stejných vyučovacích cílů, technik a metod dojde u všech učících se osob k naprosto stejným interpretacím a výsledkům učení. A to se týká nejen procesu učení se ve škole, ale také v muzeu, kde se taktéž na procesu osvojování si informací a jejich interpretaci podílejí osobní charakteristiky návštěvníka, stejně jako i jeho dřívější znalosti a zkušenosti. ${ }^{23}$ Ve výsledku pak jde o to, že $\mathrm{v}$ rámci stejné muzejní expozice si nikdy všichni návštěvníci neodnesou univerzálně totožnou informaci, předkládaný muzejní narativ nebudou vnímat univerzálně jednotně a tak i v kontextu národní identity budou konstruovat více či méně odlišná pojetí této identity.

Různí návštěvníci si tedy mohou z muzea odnášet zcela jiný dojem, zkušenost a získané informace, které nemusejí odpovídat cílům a očekávaným informačním přínosům, jež si za hlavní stanovili tvůrci expozice. $\mathrm{Z}$ tohoto pohledu není konstrukce významů v muzeu tedy jen o tom, co si muzeum přeje naučit

\footnotetext{
23 Srov. HEIN, George E. The Challenge and Significance of Constructivism. In Hands-On! Europe Conference. London, 2001, s. 35-42; HEIN, George E. Is Meaning Making Constructivism? Is Constructivism Meaning Making? The Exhibitionist, 1999, roč. 18, č. 2, s. 15-18; HEIN, George E. Evaluating Teaching and Learning in Museums. In HOOPER-GREENHILL, Eilean (ed.). Museum, Media, Message. London: Routledge, 1995, s. $189-203$.
} 
své návštěvníky, ale spíše o tom, jaké významy si návštěvníci z expozice odvodí a odnesou jako součást zkušenosti. Nelze tedy očekávat, že učení $\mathrm{v}$ muzeu bude mít přesný a předvídatelný průběh. Návštěvník se na učícím procesu sám musí podílet, být $\mathrm{k}$ němu motivován, aktivně odhalovat skrytou podstatu a smysl předkládaných objektů a narativů. Zkušenosti návštěvníků, které se do tohoto procesu zapojují, se přitom netýkají jen samotné expozice, ale souvisejí také s architekturou muzea a komfortem, který muzeum svým návštěvníkům nabízí či nenabízí (toalety, občerstvení, prostor k sezení apod.), se zážitky spojenými s cestou do muzea, se vstupným apod. ${ }^{24}$

Ze své podstaty tak konstruktivistické teorie učení mírní kritiku výše zmíněných kritických teorií muzea a to tím, že upozorňují právě na fakt, že muzeum nikdy nemůže naučit všechny své návštěvníky plně a univerzálně tomu, co jeho expozice a její tvůrci zamýšlí. Není to reálné, nebot každý z návštěvníků si do muzea přináší vlastní interpretační rámce, znalosti i zkušenosti, na jejichž základě dochází $\mathrm{k}$ aktivní konstrukci nových významů, které se pak logicky mohou lišit od významů, které dané expozici přikládají další návštěvníci muzea stejně jako i její tvůrci.

Totéž pak platí i pro proces konstrukce národní identity odehrávající se v muzeu. Také do procesu konstrukce národní identity se krom konkrétních muzejních předmětů a narativů prolínají také specifické vlastnosti a charakteristiky jednotlivých návštěvníků. Tím jsou konstruktivistické teorie učení pro kontext zkoumání procesu konstrukce národní identity $\mathrm{v}$ prostředí muzea významné, nebot nabízejí

24 FALK, John H., Lynn D. DIERKING a Marianna ADAMS. Living in a Learning Society: Museums and Free-choice Learning. In MACDONALD, Sharon (ed.). A Companion to Museum Studies. Malden: Wiley-Blackwell, 2006, s. 323-339. druhý úhel pohledu ke kritickým teoriím muzea. Extrémně kritický přístup $\mathrm{k}$ muzeím, který by vnímal muzea pouze a jen jako mocenské a ideologické instituce, které jsou schopny ovlivnit postoje a pojetí všech svých návštěvníků v předem stanovené podobě, není žádoucí a ani objektivně reálný. Muzeím nelze přisoudit stoprocentní monopol a neomylně cílený a spolu s tím i univerzálně úspěšný výsledek působnosti na proces osvojování si konkrétních informací a postojů svých návštěvníků. Zároveň ale nelze zpochybnit, že v mnoha ohledech mají i tzv. kritické teorie muzea pravdu a tím i nezastupitelné místo na poli muzejní pedagogiky a muzejního výzkumu (tj. že moc a ideologická funkce je $\mathrm{v}$ muzeích opravdu přítomná, avšak jejich př́tomnost nelze nahlížet izolovaně od dalších muzeum utvářejících faktorů). Proto je vhodné, aby byl výzkumník obeznámen s oběma póly této diskuze a obě proměnné (jak mocenský rovinu muzea, tak i subjektivitu procesu tvorby významů a osvojování si informací) si uvědomil a do své analýzy a výzkumné činnosti je začlenil.

\section{MUZEJNÍ VÝZKUM PUBLIKA A JEHO VÝVOJ: OD ANALÝZY DEMOGRAFICKÝCH CHARAK- TERISTIK PUBLIKA KE STUDIU JEHO ZKUŠENOSTI}

Fenomén muzejního výzkumu není statický a jeho povaha se $\mathrm{v}$ průběhu let měnila a vyvíjela, což se samozřejmě odrazilo i na současné povaze zkoumání národní identity v muzeu. $S$ problematikou národní identity se nevyhnutelně pojí zájem o publikum muzea, které se $s$ tímto jevem při svých návštěvách muzea setkává. V muzejním prostředí se přitom výzkumy publika zcela přirozeně uskutečňovaly již v minulosti. První výzkumy byly především kvantitativního ${ }^{25}$ charakteru a zá-

\footnotetext{
25 Kvantitativní výzkum charakterizuje Ragin (in RAGIN, Charles. Constructing Social Research. London: Pine Forge Press, 1994, s. 47-53) jako
}

jmem výzkumníků bylo zjistit, jací lidé muzea navštěvují. ${ }^{26}$

Dle mnohých výzkumư ${ }^{27}$ se ukázalo, že typické publikum muzea a galerie je obvykle vzdělanější a má vyšší plat, než je běžné u průměrné populace. Celkově vzato spadají návštěvníci muzea a galerie spíše do vyšší společenské třídy a členové menšinové populace bývají v publiku nedostatečně zastoupeni. $S$ podobnými závěry přitom přišel už v 60. letech 20. stol. Bourdieu, jehož výzkum se stal inspirací pro mnoho dalších badatelů. Pozornost Bourdieho a jeho spolupracovníků byla věnována publiku uměleckého muzea, které se dle výsledků jím provedeného výzkumu „rekrutuje předevšim z lidí vyšších společenských vrstev a vyššího vzdělání. “28 Tento fakt přitom Bourdieu vysvětluje odlišnou podobou vlastněného sociálního kapitálu u jednotlivých společenských tříd, kdy návštěva uměleckého muzea jakožto instituce vysoké kultury je príistupnější a srozumitelnější právě pro jedince z vyšších společenských tříd, kteří jsou vlastníky požadovaného sociálního kapitálu, v tomto případě „Znalostí konvencí a kódů, které

\footnotetext{
výzkum studující vztahy mezi proměnnými.

vlastností proměnných u mnoha případů. Kvantitativní výzkum je vhodný pro odhalování obecných vzorů a vztahů, testování teorií a tvoření prognóz. Dle Dismana (in DISMAN, Miroslav. Jak se vyrábí sociologická znalost: Př́ručka pro uživatele. Praha: Karolinum, 2000.) je kvantitativní výzkum charakteristický silnou standardizací (a tím způsobenou vysokou reliabilitou, ale nižší validitou), získáváním informací o velkém počtu respondentů, možností generalizace na populaci, ale také silnou redukcí počtu proměnných i vztahů mezi nimi.

26 HOOPER-GREENHILL, Eilean. Studying Visitors. In MACDONALD, Sharon (ed.). A Companion to Museum Studies. Malden: Wiley-Blackwell, 2006, s. 362-376.

27 srov. HOOPER-GREENHILL, Eilean. Audiences - A Curatorial Dilemma. In PEARCE, Susan. Art in Museums. London: Athlone Press, 1995, s. 143-163; SCHUSTER, J. The Public Interest in the Art Museum's Public. In PEARCE, Susan. Art in Museums. London: Athlone Press, 1995, s. 109142; WEST, Shearer. The Devaluation of ,Cultural Capital': Post-Modern Democracy and the Art Blockbuster. In PEARCE, Susan. Art in Museums. London: Athlone Press, 1995, s. 74-93.

28 KESNER, Ladislav. Marketing a management muzeí a památek. Praha: Grada, 2005, s. 98.
} 
umožňuji dešifrovat umělecká díla.“29 Trávení volného času v uměleckém muzeu je tak určeno spíše elitám, pro které jsou místní díla srozumitelnější a dostupnější.

Přestože je tento výzkum a jeho výsledky nutné chápat v kontextu dané doby, je důležité zmínit, že i pozdější výzkumy zabývající se analýzou složení publika dospěly ke stejným demografickým charakteristikám publika jako Bourdieu. Celkově vzato tedy $\mathrm{z}$ těchto výzkumů vyplývá, že jsou návštěvníci muzea spíše vzdělanější, mají vyšší příjmy, je pro ně typický vyšší sociální status (vyšší střední třída, studenti, inteligence apod.), podíl žen převažuje nad mužskými návštěvníky a etnické, ale i další menšiny (př. zdravotně handicapovaní) jsou v publiku muzea jen marginálně zastoupeny. ${ }^{30}$ Zpřístupnění muzejní expozice pro tyto skupiny je proto pro muzejní pracovníky (stále) aktuální výzvou.

\section{Dle Hooper-Greenhill ${ }^{31}$ si dnes} mnohá muzea uvědomují stávající situaci a snaží se svými expozicemi přilákat pozornost i jiných společenských skupin, např. menšin, díky čemuž je složení dnešních návštěvníků muzea o něco pestřejší a širší, než tomu bylo dříve. Etnické skupiny ale nejsou jediné skupiny, kterým muzea věnují specifickou pozornost. Skupiny návštěvníku mohou být také definovány na základě věku, příslušnosti $\mathrm{k}$ určité skupině, jakou může být rodina či škola, nebo vzhledem ke svým specifickým potřebám - lidé s postižením nebo se specifickým životním stylem apod. Moderní muzea by proto dle Hooper-Greenhill ${ }^{32}$ měla

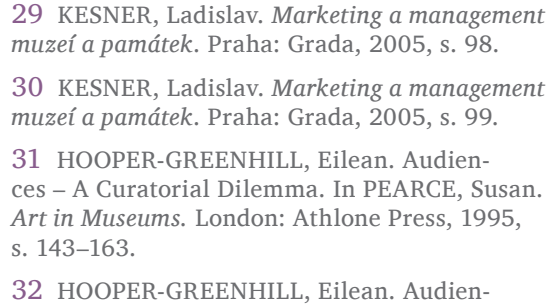

ke svému publiku přistupovat spíše $\mathrm{z}$ pozice cílů směřovaných na konkrétní cílové skupiny, jejich potřeby a zájmy, než jako k velké amorfní hmotě. Dle Wortse ${ }^{33}$ se dnes mnohá muzea snaží posunout do centra kulturního dění místních komunit, $s$ cílem stát se pro lidi důležitějším místem. Moderní muzea se tedy snaží orientovat svou činnost na publikum, tj. místní veřejnost.

S tím souvisí i orientace výzkumů, které se dle Hooper-Greenhill ${ }^{34}$ v 21. století zaměřují právě na publikum a jeho zkušenost, která se začala nově zkoumat a obohatila tak dřívější výzkum zaměřený na analýzu demografických charakteristik návštěvníků. V rámci muzejních výzkumů publika tak došlo k posunu od výzkumů kvantitativních do oblasti výzkumů kvalitativních, ${ }^{35}$ nebot výzkumníkům už nestačilo získat odpověd' na otázku, kdo muzea navštěvuje, nýbrž je začalo zajímat i to, proč a jak tak návštěvníci činí. Výzkumy se zaměřily na snahu pochopit, jakou hodnotu pro návštěvníka v muzeu nabytá zkušenost nese. K pochopení pocitu, který návštěvníci v muzeu zažívají a smyslu, který vytvářejí a přikládají expozici, už přitom nelze pouze sledovat, co návštěvníci v muzeu dělají, nebo monitorovat, jaké jsou

\footnotetext{
Art in Museums. London: Athlone Press, 1995, s. $143-163$.

33 WORTS, Douglas. Extending the Frame: Forging a New Partnership with the Public. In PEARCE, Susan. Art in Museums. London: Athlone Press, 1995, s. 164-191.

34 Srov. HOOPER-GREENHILL, Eilean. Audiences - A Curatorial Dilemma. In PEARCE, Susan. Art in Museums. London: Athlone Press, 1995, s. 143-163; HOOPER-GREENHILL, Eilean. Studying Visitors. In MACDONALD, Sharon (ed.) A Companion to Museum Studies. Malden: Wiley-Blackwell, s. 362-376.

35 Kvalitativní výzkum definují Švaříček a Šed'ová (in ŠVAŘÍČEK, Roman a Klára ŠEĎOVÁ. Kvalitativní výzkum v pedagogických vědách. Praha: Portál, 2007, s. 17) jako „proces zkoumání jevu a problémů $v$ autentickém prostředí s cílem získat komplexní obraz těchto jevů založených na hlubo kých datech a specifickém vztahu mezi badatelem a účastníkem výzkumu. Záměrem výzkumníka provádějicího kvalitativní výzkum je za pomoci celé rady postupů a metod rozkrýt a reprezentovat to, jak lidé chápou, prožívají a vytvářejí sociální realitu."
}

jejich demografické charakteristiky. Podle Hooper-Greenhill ${ }^{36}$ je spíše nutné studovat jejich interpretační strategie. Věnovat pozornost tomu, jak předkládané informace sami hodnotí, chápou a interpretují a celkově jakou zkušenost $\mathrm{v}$ muzeu zažívají. Dle Kesnera ${ }^{37}$ tak došlo k formování se pokročilejších a složitějších výzkumů zaměřených „na poznání psychologických postojů a motivací, jež determinují rozhodování lidí v oblasti životního stylu a volného času a na možnosti jejich ovlivňování, případně prekonávání bariér, daných př́slušností $k$ určité sociodemografické skupině."

\section{Výzkumy zajímající se o „kvalitu“} a nejen „kvantitu“ návštěvníka muzea pomalu dospěly k závěru, že diváci nejsou pasivní masou submisivně přijímající předkládané informace, nýbrž se na tvorbě významů sami aktivně podílejí. To obrátilo pozornost $\mathrm{k}$ faktu, že se na procesu učení se v muzeu nepodílí pouze předkládané informace, nýbrž celá prožitá zkušenost - a to jak zkušenost zažitá v muzeu, tak životní zkušenosti návštěvě muzea předcházející i bezprostředně návštěvě následující. ${ }^{38}$ Postupem času se tak do popředí zájmu muzejní pedagogiky dostaly výše zmíněné konstruktivistické teorie učení, které v procesu učení zohledňují právě učícího se osobnost a předchozí zkušenost, dosavadní znalosti a osvojené interpretační rámce.

Celkově s cílem zlepšovat muzejní nabídku dle Kesnera ${ }^{39}$ došlo k roz-

\footnotetext{
36 HOOPER-GREENHILL, Eilean. Studying Visitors. In MACDONALD, Sharon (ed.). A Companion to Museum Studies. Malden: Wiley-Blackwell, s. $362-376$.

37 KESNER, Ladislav. Marketing a management muzeí a památek. Praha: Grada, 2005, s. 101.

38 Srov. HOOPER-GREENHILL, Eilean. Audiences - A Curatorial Dilemma. In PEARCE, Susan. Art in Museums. London: Athlone Press, 1995, s. 143-163; HOOPER-GREENHILL, Eilean. Studying Visitors. In MACDONALD, Sharon (ed.). A Companion to Museum Studies. Malden: Wiley-Blackwell, s. 362-376.

39 KESNER, Ladislav. Marketing a management muzeí a památek. Praha: Grada, 2005, s. 102, 134.
} 
voji výzkumů zaměřujících se na zkoumání dynamiky spotřeby kulturního produktu, na vzorce vnímání kulturních artefaktů, využívání doprovodných služeb, studium chování rodin či skupin v muzeu a analýzu psychologických a kognitivních dimenzí muzejní návštěvy a to s cílem zlepšení edukačních programů apod. Častým typem výzkumu probíhajícího v muzeu je pak také marketingový výzkum, který se zajímá především o návštěvníkovy postoje, přaní, motivy a hodnocení ve snaze zvýšit návštěvnost muzea, podpořit propagaci muzea, zintenzivnit spokojenost návštěvníků, získat informace o tržních silách a návštěvnosti. Získané informace ale mohou sloužit také pro přípravu expozice či odborných a edukačních programů. Výzkumy probíhající v muzeu si tak mohou klást rozličné cíle a otázky, vzhledem ke kterým volí i metodologické nástroje nejlépe vyhovující konkrétnímu výzkumnému záměru. Nejčastěji jde o dotazníky, osobní či skupinové rozhovory (s návštěvníky či zaměstnanci muzea), pozorování či experimentální metody sloužící k testování expozic a výstav, obsahové analýzy muzejních dokumentů a muzejnědidaktických materiálů apod. ${ }^{40}$

V prostředí muzea se pak může odehrávat, jak upozorňuje Jagošová, Jůva, Mrázová, ${ }^{41}$ ještě jeden typ výzkumu a to muzejněpedagogický výzkum, jenž je subdisciplínou muzejní pedagogiky. „Empirický výzkum v muzejní pedagogice zkoumá konkrétní muzejněpedagogickou realitu,“42 přičemž může jít o výzkumy zaměřené na zkoumání profese mu-

40 Srov. KESNER, Ladislav. Marketing a management muzeí a památek. Praha: Grada, 2005; JAGOŠOVÁ, Lucie, Vladimír JƯVA a Lenka MRÁZOVÁ. Muzejní pedagogika: metodologické a didaktické aspekty muzejní edukace. Brno: Paido, 2010.

41 JAGOŠOVÁ, Lucie, Vladimír JŮVA a Lenka MRÁZOVÁ. Muzejní pedagogika: metodologické a didaktické aspekty muzejní edukace. Brno: Paido, 2010, s. 118-128.

42 JAGOŠOVÁ, Lucie, Vladimír JŮVA a Lenka MRÁZOVÁ. Muzejní pedagogika: metodologické a didaktické aspekty muzejní edukace. Brno: Paido, 2010, s. 118. zejního pedagoga, výzkumy orientující se na proces učení se $v$ muzeu, studie zaměřené na problematiku muzejní edukace, analýzu sociální role muzea, výzkum muzejního návštěvníka a muzejní návštěvnosti, evaluace muzejněpedagogických aktivit, zkoumání vlivu digitálních medií pojících se $s$ muzeem, monitorování spolupráce muzea a školy či jiných institucí, výzkumný zájem o sociální klima muzea apod. Společným cílem muzejněpedagogických výzkumů bývá především snaha o to pochopit a zdůraznit význam procesu učení a vzdělávání v muzeu a vymezit roli a funkci muzea v soudobém světě. Tato funkce je přitom stále neoddělitelně spjatá také s národní identitou a procesem její konstrukce a osvojování si jí v muzeu konkrétními návštěvníky.

\section{NÁRODNÍ IDENTITA A MUZEJNÍ VÝZKUM}

Nadcházející pasáž textu představí tři výzkumné studie zabývající se problematikou konstrukce a prezentace národní identity v muzeích. Výběr studií zařazených do analýzy byl realizován $\mathrm{v}$ rámci elektronických databází EBSCO, Web of Science, ProQuest a ERIC a to prostřednictvím zadaných klíčových slov v českém, slovenském a anglickém jazyce. Na základě takto vybraných souborů a analýz jejich anotací byly zvoleny tři výzkumné projekty, které byly realizovány nejpozději v uplynulých 6 letech (konkrétně v letech 2010 až 2014). Šlo o studie nejrelevantnější z hlediska diskutovaného tématu konstrukce a prezentace národní identity $\mathrm{v}$ prostředí muzea a jejího výzkumu, i vzhledem ke kvalitě výzkumné metodologie, která byla ve všech třech př́padech kvalitativního charakteru.

První ze studiii ${ }^{43}$ pochází z německého výzkumného prostředí a zabý-

43 Nation and National Museums, a Contested Relationship: An Analysis of US. National Museums in the Twenty-first Century. Curator: The Museum Journal, 2014, roč. 57, č. 1, s. 97-106. vá se otázkou konstrukce národní identity v rámci národních muzeí Spojených států amerických. Druhá studie $^{44}$ evropského rozměru byla zaměřena na evropská národní muzea, konkrétně Estonsko, Lotyšsko, Řecko, Německo, Irsko, Skotsko a zajímala se o to, jak se národní muzea podílejí na vnímání pojmu národa a budování národní identity u návštěvníků starších 18 let. Třetí studie $^{45}$ se zaměřila na skotskou národní identitu a její vnímání návštěvníky ve věku 13 až 18 let.

Vybrané studie se orientují na různá národní muzea nacházející se $v$ Evropě a USA. Jednotlivá muzea tak pocházejí z odlišného kulturního prostředí, přičemž je nutné si uvědomit, že výsledky výzkumu (stejně jako charakter muzeí samotných) bývají těmito sociokulturními zvláštnostmi dané země jakožto i konkrétního muzea determinovány. To se projevilo např. ve výzkumu autorů Dodd, Jones, Sawyer a Tseliou ${ }^{46} \mathrm{v}$ rámci řeckého muzea, kdy vzhledem ke specifickým společenským podmínkám převládajícím v době výzkumu v Řecku (,řecká krize") bylo muzeum jeho návštěvníky vnímáno ve zcela specifických kontextech a mnozí návštěvníci pojímali muzeem konstruovanou národní identitu jako prostředek ujištění o síle a nezdolnosti řeckého národa, který se dokáže vyrovnat se současnou problematickou situací.

Spolu s kulturní odlišností jednotlivých muzeí se liší také kulturní zázemí jednotlivých výzkumných

\footnotetext{
44 Voices from the Museum: Qualitative Research Conducted in Europe's National Museums. EuNaMus Report No 6. (Linköping University Interdisciplinary Studies 17). Sweden: Linköping University Electronic Press, 2012.

45 LLOYD, Katherine. Beyond the rhetoric of an "inclusive national identity": Understanding the potential impact of Scottish museums on public attitudes to issues of identity, citizenship and belonging in an age of migrations. Cultural Trends, 2014, roč. 23, č. 3, s. 148-158.

46 Voices from the Museum: Qualitative Research Conducted in Europe's National Museums. EuNaMus Report No 6. (Linköping University Interdisciplinary Studies 17). Sweden: Linköping University Electronic Press, 2012.
} 
týmů a autorů daných studií. Tyto proměnné mohou ovlivnit jak samotný charakter výzkumu, jeho orientaci i průběh, tak i jeho výsledky a výzkumná zjištění. Cílem přehledové studie přitom není zobecnit výsledky předkládaných výzkumných studií za cílem vytvořit jediný obecně platný model, nýbrž spíše poukázat na důležité výzkumy na dané téma a spolu s tím představit metodologii, která se ve výzkumu národní identity v prostředí muzea v současné době uplatňuje a tuto metodologii zhodnotit.

Výzkumným tématem, od kterého se analýza předkládaných studií odvíjí, je národní identita v muzeích, její konstrukce skrze dominantní muzejní narativy a spolu s tím neodmyslitelně i její interpretace z pozice tvůrců expozic či jejich návštěvníků. Vedle zájmu o význam a konstrukci národní identity v muzeích věnuje analýza studií pozornost také metodologii, kterou vybrané výzkumy používají ve snaze poukázat na současný muzejní diskurs týkající se výzkumu národní identity v muzeích.

Cílem analýzy vybraných výzkumných studií je tedy nabídnout ukázku toho, jak může současný muzejní výzkum orientující se na tematiku národní identity probíhat a k jakým závěrům tento typ výzkumu může dospět. Za tímto účelem si analýza klade tři výzkumné otázky, které následně zodpovídá v rámci jednotlivých podkapitol pojednávajících o daných studiích. Výzkumné otázky zní: Jakou metodologii vybrané výzkumy používaly? O co konkrétně se vybrané výzkumy národní identity v muzeu zajímaly? K jakým podstatným zjištěním týkajících se národní identity vybrané výzkumné studie došly?

\section{Prezentace národní identity v rámci národních muzeí v USA}

Autory výzkumu jsou Drengwitz, Elbers, Jahn a Wrogemann, ${ }^{47}$ tehdejší studenti kulturálních studií na Leuphana University of Lueneburg v Německu, kteří se věnují otázce prezentace představ o národní identitě v rámci národních muzeí Spojených států amerických spojenou s tím, jak tato muzea reagují na proměnu národní identity, která se v globalizovaném světě odehrává. Cílem jejich výzkumu bylo zjistit, jakou úlohu sehrávají vybraná americká muzea $\mathrm{v}$ rámci konstrukce a prezentace národní identity a jak se do pohledu na národní identitu promítají současné globalizující tendence - tedy zda jsou muzeem prezentované národní identity homogenní či partikulární povahy. Téma homogenity a plurality prezentace národních identit $\mathrm{v}$ muzeu je přitom ústředním bodem, od nějž se odvíjí informační přínos výzkumu.

Výzkum uskutečněný v roce 2012 se prováděl v rámci 6 amerických národních muzeí (jednalo se o National September 11 Memorial Museum a o 5 muzeí spadajících pod Smithsonian Institution: National Portrait Gallery, National Museum of American History, National Museum of the American Indian, National Museum of Air and Space, Hirshhorn Museum and Sculpture Garden). Metodologie výzkumu byla kvalitativní povahy. Nástrojem sběru dat byly nestandardizované rozhovory s experty, tj. s kurátory, řediteli muzea a designéry výstav ( $\mathrm{v}$ průměru trvaly asi 90 minut). Jejich cílem bylo zjistit, jaký postoj muzeum zaujímá ke konceptu národní identity a národa. Jednotlivé otázky se zaměřovaly na témata posilování národní identity, na integraci kritické perspektivy, stejně jako na osobní názory a postoje $\mathrm{k}$ národní (ame-

47 In Nation and National Museums, a Contested Relationship: An Analysis of US. National Museums in the Twenty-first Century. Curator: The Museum Journal, 2014, roč. 57, č. 1, s. 97-106. rické) identitě tázaných pracovníků muzea. Rozhovory byly následně analyzovány a interpretovány za pomocí kvalitativní obsahové analýzy (vycházející z autorské dvojice Glaser a Lauder).

Co je důležité, autoři výzkumu si uvědomovali, že ve výzkumu zkoumaná muzea nelze vnímat homogenně, nebot jednotlivá muzea nabývají různých podob, poněvadž odrážejí rozličné zájmy a očekávání různých sociálních a politických skupin. Jak ale výzkum ukázal, přes veškerou odlišnost měla většina muzeí jednu společnou charakteristiku a to tu, že se zakládala na silném konceptu homogenní národní identity, jež byla prostřednictvím tradičních narativů předkládána „shora“ a podílela se tak na funkci muzea jako důležitého reprezentanta národní identity. Prezentace pluralitních identit se tak v tomto prostředí dle autorů jeví jako takřka nemožná, byt' je jinak pro z mnoha států složené USA typická. Autoři tak nastiňují problém, zda jsou takováto muzea stále legitimní a kladou si otázku, zda existuje něco, co uchovává národní muzea národně významnými pro všechny různorodé obyvatele.

V kontextu problematiky národních muzeí je přitom nutné si uvědomit kontext vzniku a fungování těchto muzeí. Podmínkou vzniku národních muzeí byli dle Andersona ${ }^{48}$ koncept a idea národa. Národní muzea se měla v době šírícího se nacionalismu podílet na posilování a konstruování národní identity, která se odvíjela především od narativů prezentujících jedinečnou národní historii. Tradiční hodnoty, na nichž byla muzea vystavěna (prezentace a konstrukce národní identity) dnes ale prošly poststrukturalistickou a postmoderní kritikou a revizí. V současnosti

48 Nation and National Museums, a Contested Relationship: An Analysis of US. National Museums in the Twenty-first Century. Curator: The Museum Journal, 2014, roč. 57, č. 1, s. 98. 
přestala být historie vnímána jako objektivní fakt a začalo na ni být pohlíženo jako na konstruovanou, subjektivní a křehkou záležitost. Navíc se objevují názory, že pro dnešní mladou generaci už národní identita není základním referenčním bodem, od kterého odvozuje svou identitu, nebo se ve společenských vědách pracuje s Hallovým konceptem „hybridní identity“. To je důvodem toho, že byla koncepce dominantní národní identity, jakožto myšlenka, na níž byla do té doby národní muzea postavena, $\mathrm{v}$ mnoha případech zpochybněna. Proměna pojetí konceptu národní identity se pak samozřejmě promítá také do postavení národní identity $\mathrm{v}$ muzeu a do podoby a fungování muzea samotného.

Vyplývá z toho, že dnešní národní muzea mají různou podobu. Proto i v rámci výzkumu bylo možné sledovat rozdíly $\mathrm{v}$ pojetí národní identity i její prezentace např́čc jednotlivými národními muzei. Některá muzea stále fungují jako místa oslavy národních symbolů a identit. Mnohá muzea byla reprezentanty koherentní identity (např. National Museum of Air and Space), jiná upřednostňovala vizi plurality a kladla si za cíl v rámci expozic nabízet široké pole prezentovaných identit a pokoušet se vytvářet moderní post-národní expozice, které díky prezentaci různých identit a př́iběhů více odpovídají dnešnímu globalizovanému světu (to byl příklad Hirshhorn Museum and Sculpture Garden).

Vytvářet expozice bohaté na pluralitní identity a příběhy ale pro národní muzea není snadné. Dle výsledků předkládaného výzkumu jsou totiž národní muzea v kontextu prezentace národní identity strukturálně omezovaná a to $\mathrm{s}$ ohledem na finance (závislost muzea na více finančních zdrojích), zájmy zaangažovaných stran, politiků a lobbistů, návštěvnost, požadavky a očekávání návštěvníků, vlastní zaměřenost a tematičnost muzea apod. Všechny tyto faktory ovlivňují, nakolik jsou muzea schopna a ochotna nabízet partikulární reality a obsahy. Jako příklad uvádějí autoři výstavu týkající se atomového bombardování měst Hirošimy a Nagasaki za druhé světové války, jejichž vyobrazení $\mathrm{v}$ rámci expozice bylo silně mocensky podmíněno a omezeno. Kurátoři výstavy totiž museli z expozice vyřadit jakékoli informace poukazující na odpovědnost Ameriky za tento čin. Jiným př́́kladem mohou být kontroverzní výstavy, na které bývá složité sehnat peníze a tak je pro kurátory obtížné je zrealizovat. To se přitom týká především nejstarších národních muzeí, která jsou v očích návštěvníků i sponzorů ustálená v pojetí klasických reprezentantů všeobecné národní identity. Historicky mladší muzea a muzea, která nejsou vnímána jako zastřešující jednotnou národní identitu (často muzea, která nenesou v názvu pojmenování „národní“) mají situaci o něco jednodušší. Například muzea umění nebývají tolik politicky podmíněná jako právě národní muzea. Všeobecně tak lze dle autorů shrnout, že aktuální globalizací měnící se situace je pro muzea složitá, nebơ jsou postavena před nelehkou volbu směru cesty a pozice $\mathrm{v}$ rámci měnící se společnosti.

Dle autorů výzkumu by přitom muzea neměla zapomínat na svůj velký potenciál v možnosti prezentovat narativy pojící se s velkou škálou sociálních a kulturních skupin a tohoto potenciálu by se měla snažit využívat a to i na úkor možného narušení jejich pojetí jako místa reprezentujícího unifikované a svrchované identity. Jak už ale bylo řečeno, využít těchto šancí je pro jednotlivá muzea různě obtížné a tak např. pro National Museum of the American Indian, které se snaží vyjednat pozici, v nímž je možné prezentovat současnou multietnickou společnost a její heterogenní identity (zapojuje se zde snaha „dát hlas“ i členům minoritních identit a podívat se na prezentované objekty a situace jejich úhlem pohledu), bude mnohem jednodušší zařadit do své nabídky více rozmanitých narativi̊, zatímco pro historické National Museum of American History, které je vnímáno jako významný a silný reprezentant americké kultury a identity, bude reakce na proměňující se společenské struktury a požadavky náročnější a tak i mnohem pozvolnější. Ovšem i National Museum of the American Indian se ve své snaze prezentovat heterogenní identity potýká s řadou problémů - musí např. nacházet kompromis mezi potřebami menšinových kultur, které chce prezentovat, ale zároveň i mezi požadavky Smithsonian Institution (jeho provozovatele), který je zástupcem spíše většinové politiky. Stejně tak vždy hrozí riziko, že výsledná expozice bude pouze jakýmsi reprezentantem smíšené a povrchní identity přistěhovalců či rodilých Američanů, nebot' není v možnostech výstavy detailně a hloubkově prezentovat všechny rozmanité kulturní a národní skupiny a tak často dochází $\mathrm{k}$ vytvoření obrazu obecné domorodé kultury, která ale již neodpovídá kultuře jednotlivých skupin a jejich pluralitě.

Závěrem lze dle autorů shrnout, že míra, jakou jsou americká národní muzea zapojena do procesu tvorby a reprezentace homogenní národní identity, či naopak do snahy vytvářet prostor pro vnímání identit jako různorodých fenoménů, je u jednotlivých muzeí odlišná. Důraz na národní identitu však zůstává stále velmi silný a to i přes mnohé názory, které tvrdí, že vliv nacionalismu v rámci každodenního života lidí dnes již klesá. Pojem národa v muzeu zůstává stále důležitou kategorií, at už se jedná o jeho prezentaci a konstrukci ve snaze posílit národní homogenitu či naopak podpořit uvědomění si národnostní heterogenity a plurality společnosti, či o vy- 
jednávání pozice $\mathrm{v}$ rámci působení obou těchto tendencí a snahu nalézt rovnováhu mezi nimi.

\section{Evropská národní muzea a jejich pojetí národní identity}

Předkládaná výzkumná zpráva autorů Dodd, Jones, Sawyer a Tseliou ${ }^{49}$ byla vyhotovena $\mathrm{v}$ rámci tř́letého výzkumného programu EuNaMus (2010-2013): European National Museums: Identity Politics, the Uses of the Past and the European Citizen koordinovaném $\mathrm{v}$ rámci Linköping University ve Švédsku. Aktivity $\mathrm{v}$ rámci projektu byly rozděleny do šesti výzkumných oblastí směřujících k získání finální odpovědi na otázku, jak mohou národní muzea přispět k procesu sociální změny, přičemž předkládaný výzkum je jedním z nich.

Výzkumný projekt byl řízen interdisciplinárním týmem složeným ze zástupců ze tři univerzitních institucí: University of the Aegean v Řecku, University of Tartu v Estonsku a University of Leicester ve Velké Británii. Výzkum se odehrával v roce 2011 (pilotní výzkum byl proveden $\mathrm{v}$ roce 2010 ve skotském národním muzeu) $\mathrm{v}$ rámci 6 národních muzeí: Estonian National Museum (Tartu), Latvian Open-Air Museum (Riga); National History Museum (Athény, Řecko), German Historical Museum (Berlín), National Museum of Ireland (Dublin), National Museum of Scotland (Edinburgh). V rámci těchto muzeí pak vzniklo 6 případových studií, přičemž v jejich rámci získané informace byly dále zpracovávány.

Cílem výzkumného projektu bylo porozumět tomu, jak fungují národní muzea $\mathrm{v}$ rámci veřejnosti a jak se podílejí na vnímání pojmu

\footnotetext{
49 Voices from the Museum: Qualitative Research Conducted in Europe's National Museums. EuNaMus Report No 6. (Linköping University Interdisciplinary Studies 17). Sweden: Linköping University
} Electronic Press, 2012. národa a evropanství, jak se muzeem prezentovaná minulost podílí na budování národní identity návštěvníků a jak vnímají návštěvu muzea návštěvníci, kteří jsou členy většinové národnosti, či naopak zástupci národnostních menšin. Cílem projektu tak bylo poskytnout vhled do problému, jak návštěvníci národních muzeí např́ič Evropou vyjadřují představy týkající se národní identity, historie a Evropy a jakou roli $\mathrm{v}$ procesech a rozvoji vnímání těchto konceptů sehrává právě národní muzeum. Výzkum prìtom kladl důraz na to, že muzea nelze vnímat pouze jako místa, která předávají dílčí informace a identity, ale také jako místa, v nichž se na pochopení informací a tvorbě identit návštěvníci aktivně podílejí s ohledem na své osobnostní, sociokulturní, zkušenostní, znalostní a další charakteristiky. Výzkumná studie se proto zajímala o problematiku, jakým způsobem návštěvníci využívají národních muzeí a jejich expozic v procesu konstrukce jejich vlastní (národní) identity.

Metodologie výzkumu byla kvalitativního charakteru a probíhala prostřednictvím polostrukturovaných rozhovorů a ohniskových skupin s respondenty. Podmínkou výzkumného vzorku bylo, že návštěvníci zahrnuti do výzkumných rozhovorů museli být starší 18 let a $2 / 3 \mathrm{z}$ nich museli být členy národa, jenž dané národní muzeum reprezentovalo. Výzkumný vzorek celkem čítal 166 respondentů. Jelikož se ukázalo, že složení respondentů výzkumu mělo tendenci spadat do kategorie běžného návštěvníka muzea (tj. člen většinové populace, středoškolského či vyššího vzdělání, zaměstnaný jako nemanuální pracovník, pravidelně navštěvující muzea), byla vytvořena ještě ohnisková skupina složená z 22 osob, jejíž členové byli reprezentanty $\mathrm{v}$ dané zemi uznané menšiny a tedy osob, které muzeum zpravidla běžně nenavštěvují a jejichž úhel pohledu obvykle nebývá $\mathrm{v}$ muzeu prezentován (nedostatečnou či zcela chybějící prezentaci zkušeností menšin $\mathrm{v}$ rámci vybraných muzeí potvrdil i tento výzkum). Samotný sběr dat byl prováděn zainteresovanými univerzitami a jejich týmy. Následně byla sesbíraná data zpracována (přepis dat, př̀klad do angličtiny, analýza a interpretace případových studií) a předána týmu z University of Leicester, který získaná data analyzoval, interpretoval a porovnal napříč všemi třemi zkoumanými muzei a vytvořil obecnou a závěrečnou výzkumnou zprávu.

Přejdeme-li ke konkrétním výsledkům výzkumné studie, je nutné hned $\mathrm{v}$ úvodu poznamenat, že v rámci výzkumu nebylo obvykle vždy možné určit, do jaké míry byly představy návštěvníků o národnosti ovlivněny národním muzeem. Mnohdy totiž nebylo reálné $\mathrm{v}$ rámci rozhovorů rozlišit jasné hranice mezi tím, jaké myšlenky a postoje v návštěvníkovi vyvolaly v muzeu čtené obsahy, a mezi myšlenkami a postoji, které si s sebou návštěvníci do muzea přinesli. Výzkumníci se tuto situaci rozhodli řešit tím, že si položili otázku, zda muzea nějakým způsobem zpochybnila stávající představu návštěvníka o národní identitě. Odpověd' na tuto otázku pak zněla „ne“. Většina návštěvníků deklarovala, že pojetí předkládaná muzeem se shodovala $s$ jejich vlastními a dosavadními představami. Na jednom konci spektra byli návštěvníci, kteří reflektovali, že národní muzeum sehrálo velkou roli v procesu utváření a posilování jejich národní identity. Tito návštěvníci často zdůrazňovali návštěvu muzea jako možnost, jak získat pocit jistoty $\mathrm{v}$ dnešním nejistém světě - především v Řecku, kde byla v době výzkumu společenská a politická situace dosti napjatá, byla zdůrazňována role muzea $\mathrm{v}$ rámci hledání historického i současného kontextu a identity. Někteří návštěvníci zde na národní identitu 
pohlíželi nostalgicky, jiní expozici využili k procesu porovnávání a konstituování identity dnešní. Celkově však výstava v očích řeckých návštěvníků obvykle poskytovala ujištění, že jsou Rekové silným národem, který zvládl útrapy již $\mathrm{v}$ minulosti a tak je zvládne a překoná i dnes. Našla se ale i taková skupina návštěvníků, kteří svou identitu či historii v muzeu vůbec jako prezentovanou neobjevili (jednalo se především o návštěvníky z menšinových skupin a cizích zemí) a podle nichž se tak muzea na procesu konstituování národní identity nepodílejí. Některými návštěvníky byla dokonce prezentace národní identity vnímána jako mající negativní dopad pojící se s vyloučením, agresí a nenávistí. $\mathrm{V}$ těchto prrípadech šlo nejen o problematiku související s nerealistickými stereotypy, ale také o jevy souvisejícími $\mathrm{s}$ válečnou historií, či o vylučování menšin $\mathrm{z}$ definice národa.

Zajímavým zjištěním je fakt, že pro většinu dotázaných respondentů byla národní identita důležitým konceptem vyjadřujícím sounáležitost $s$ komunitou či národem, v němž žijí. Národní identita byla vnímána jako jedna $\mathrm{z}$ důležitých složek osobní identity vůbec. Míra významu, jaká byla přikládána právě identitě národní, byla u jednotlivých respondentů individuální, většina respondentů však národní identitu začlenila do své osobní identity a pro mnoho respondentů to byl právě koncept národní identity, jenž použili k popisu své identity jako takové. Na identifikaci identity jedince se dále podílelo místo, kde lidé žijí a kde se narodili, region, kořeny, gender, náboženství, jazyk, vzdělání, profese a zaměstnání, role $\mathrm{v}$ rámci rodiny a osobnostní charakteristiky a zájmy.

Přestože respondenti deklarovali důležitost národního rozměru identity pro pojetí osobní identity jako takové, popsat vlastní národní identitu pro ně bylo často obtížné. Někteř́ ř́íkali, že o národní identitě nikdy přímočaře neuvažovali, nebo pro ně bylo těžké vyjádřit obecnou národní identitu $\mathrm{v}$ kontextu komplikované historie (to se týkalo především německých respondentů a jejich odkazování $\mathrm{k}$ druhé světové válce a její problematickou spjatostí $s$ dnešní německou identitou), nebo s ohledem na aktuální sociální problémy a měnící se politickou situaci (problém řeckých respondentů) apod. Někteří respondenti (celkem 13) poukazovali na problém hybridní identity, který se odvíjel od dvojitého občanství, rodinných kořenů nebo usazení se migrantů v nové zemi. Jen velmi málo respondentů ale odmítlo koncept národní identity jako takový a přihlásili se spíše k identitě evropské či kosmopolitní.

Výzkum se dále zabýval tím, jaké objekty a př́iběhy pojící se $s$ národní identitou byly pro návštěvníky významné. Identifikovat objekty a narativy mající národní význam bylo pro mnoho návštěvníků nesnadné. Interpretace důležitých narativů závisela na návštěvníkově dřívější zkušenosti a osvojených znalostech a často také na tom, $\mathrm{z}$ jaké pozice př́běh respondent interpretoval (např. $\mathrm{z}$ pozice majority či minority, nebo z pozice turisty). $\mathrm{V}$ rámci úkolu identifikovat znaky národní identity a potažmo celkově daného národa se návštěvníci shodli na těchto hlavních národnostních komponentách: specifické kulturní zvláštnosti a charakteristiky (národní duch - napřr. přátelskost, pracovitost), náboženství, jazyk, hodnoty (definované z pozice státu a z pozice lidí), vlast (přináležitost k místu), původ a kořeny, kultura a tradice, významné osobnosti (lidé bojující proti ostatním), evropské či globální vlivy. Muzeem prezentovaná národní identita byla tedy vnímána v několika rovinách. Návštěvníci často hodnotili expozici jako podporující pocit hrdosti na danou národní identitu (pýcha národa pojící se $s$ jeho lidem, historií a úspěchy). Reakce na prezentovanou národní identitu ale byly někdy i rozporuplné a některé prezentované národní stereotypy a mýty byly označeny za nepravdivé a skutečnost zakrývající. Např. ve Skotsku šlo o na turisty zaměřenou reprezentaci vrchoviny, whisky, prríšery Lochness, chov ovcí, tartan apod., což podle některých místních návštěvníků bylo velmi omezenou reprezentací Skotska a jeho národa. Naopak dva návštěvníci z cizích zemí se divili, že ve skotském muzeu nebyly žádné kilty ani dudy, které doposud tvořily základ jejich představy o skotské národnosti. $V$ těchto dvou príípadech šlo ale spíše jen o výjimku, nebot jak výzkum ukázal, návštěvníci pocházející z jiné země, než jejíž národnost muzeum prezentovalo, obvykle počítali s tím, že si do muzea nesou své referenční rámce a představy o daném národě, které mohou být stereotypní a nemusejí nutně odpovídat realitě.

Pokud zůstaneme $\mathrm{u}$ problematiky narativů, stojí za zmínku i fakt, že si návštěvníci někdy stěžovali na nepřítomnost silného jednotícího příběhu, který by provázel celou expozici či muzeum (a to hlavně ve Skotsku a Irsku). Nebo expozice prezentovaly pouze život vybraných etnických a třídních skupin (např̀. prezentace folkloru v Lotyšsku). Existovaly ale i narativy se současnou závažnou tematikou (výše zmíněné Řecko). V rámci narativů, které byly návštěvníky identifikovány jako mající vztah k národní identitě, se jednalo především o témata původu národa, zlatého věku, různých konfliktů a nepřátel a světového vlivu (např̀. historický vliv řecké civilizace, role Německa ve světových válkách, úspěchy ve vědě, průmyslu či umění apod.).

Jak je vidět, důležitou součástí národních muzeí je prezentace národní historie. Muzeum dokáže vytvářet most do minulosti a emo- 
tivně přiblížit danou minulost a zároveň ji uchovat pro příští generace. Celkově muzeum nabízí kontinuitu a kořeny, ukazuje, odkud se daný národ vzal a kam směřuje a tím buduje obraz kolektivní identity. Skrze historii národa je pak budována právě i identita národní. To potvrdil i předkládaný výzkum, z jehož výsledků vyplynulo, že historie národa a národní kořeny, které muzea prezentovala, byly návštěvníky vnímány jako důležitá součást národní identity. Mimo to starší návštěvníci zdůrazňovali význam muzea v procesu uchovávání minulosti v živé paměti, tedy ve snaze aby minulost nebyla zapomenuta. Muzea byla vnímána jako místa zachovávání paměti, jako mosty do minulosti i jako zdroje učení a poučení. Samotnými návštěvníky tak byla reflektována didaktická role muzea. Na druhou stranu se našli ale i návštěvníci, kteří si stěžovali na fakt, že muzejní narativy odkazovaly spíše na minulost, než že by se dotýkaly současnosti. Tito návštěvníci tak reflektovali problém chybějících příběhů týkajících se dnešních událostí.

V rámci předkládané výzkumné studie lze vypozorovat, že si výzkumníci při provádění kvalitativního výzkumu uvědomovali obě důležité roviny procesu v muzeu se konstruující a osvojující národní identity: národní muzeum je místem, které reprezentuje národní minulost a současnost a skrze ni tak konstruuje určitou podobu národní identity a tento obraz národní identity předkládá svým návštěvníkům. Ti však sami aktivně konstruují a produkují své vlastní porozumění národní identitě. Návštěvníci tedy využívají své osvojené referenční rámce, porovnávají je s referenčními rámci nabízenými muzeem a na základě toho si vytváří své vlastní porozumění konceptu národní identity. Návštěvníkovo výsledné pojetí národní identity tak nezávisí pouze na muzeem konstruované podobě národní identity a s ní pojících se informací, ale také na návštěvníkových dřívějších znalostech, postojích a způsobech vnímání dané expozice, v nichž se odráží nejen osobnostní charakteristiky návštěvníka, jako je jeho věk, národnost (a jeho osobní pojetí vlastní národní identity - např. příslušnost $\mathrm{k}$ menšině či většině), ale také jeho dřívější životní zkušenosti, motivace k návštěvě muzea, znalosti týkající se národa a stávající porozumění konceptu národní identity, míra víry ve spolehlivost muzea (výzkum ukázal, že většina návštěvníků vnímala muzea jako místa mající kulturní a historickou autoritu a tak tedy i důvěryhodnost a také důležitou politickou roli) apod. Toto pojetí bylo vstupním předpokladem výzkumu, který následně potvrdil fakt, že samotní návštěvníci hrají dominantní roli v procesu chápání a osvojování si národní identity v muzeu. Ukazuje se tak vliv konstruktivistických teorií učení na procesu konstrukce národní identity v muzeu, jejichž význam vyplouvá ve výzkumu na povrch, ačkoli se sami autoři k těmto teoriím nevyjadřují a ve svém výzkumu je nepojmenovávají. Jejich význam však z výsledků výzkumu jasně vyplývá.

Souhrnně tedy můžeme říci, že důležitým obecným zjištěním výzkumu je fakt, že národní identita v muzeu je spoluutvářena muzeem a jeho návštěvníky. Vliv na vnímání národní identity v muzeu měly přitom i konkrétní charakteristiky muzeí, jako jsou jejich obsahové zaměření (napřr. muzea v Lotyšsku a Estonsku prezentovala národní historii skrze ukázku tradiční lidové kultury, která ale logicky nemohla odrážet současnou národní identitu návštěvníka, mohla pouze poskytnout pohled na část minulosti), velikost muzea a umístění budovy, charakteristiky expozice a v jejím rámci využívané technologie a média (obraz, zvuk, text, interaktivita apod.) a podoba muzeem předklá- daných narativů, jejich cíle a srozumitelnost. Vliv měla také současná společenská situace dané země, její politické a společenské klima.

\section{Skotská národní identita $\mathrm{v}$ pojetí dospívajících respondentů}

Předkládaný výzkumný text autorky Lloyd ${ }^{50}$ prezentuje dílčí část autorčina disertačního výzkumu. V centru jeho zájmu byla zkušenost mladých lidí pojící se se skotskou národní identitou v kontextu utváření si představy o vlastní národní identitě a postoje $\mathrm{k}$ ní.

Výzkumný vzorek se skládal ze 73 respondentů ve věku 13 až 18 let, kteří byli žáky 6 vybraných škol z Glasgow, Edinburghu, Scottish Borders a Western Isles, kde se také odehrával samotný výzkum a sběr dat. Místo původu respondentů přitom bylo do výzkumu zahrnuto jako proměnná podílející se na procesu utváření postojů týkajících se národní identity. Samotný výzkum se pak týkal Národního skotského muzea (National Museum of Scotland) a cílem výzkumu bylo zjistit, zda se prohlídka muzejních artefaktů nějakým způsobem podílela na změně postojů dospívajících respondentů k národní identitě.

Narativní výzkumný přístup se zaměřil na zkoumání pojetí identity respondentů a byl založený na technice ohniskových skupin a polostrukturovaných rozhovorů. Ty byly nahrávány jako audio i video záznam a bezprostředně po sběru dat byly doplněny výzkumníkovými poznámkami, následně přepsány a analyzovány. Výzkum byl opřen také o techniky vizuální stimulace a to za pomocí filmu (film "One Nation, Five Million Voices", který je součástí muzejní expozice a snaží

50 LLOYD, Katherine. Beyond the rhetoric of an "inclusive national identity": Understanding the potential impact of Scottish museums on public attitudes to issues of identity, citizenship and belonging in an age of migrations. Cultural Trends, 2014 , roč. 23 , č. 3 , s. $148-158$. 
se přimět návštěvníky $\mathrm{k}$ diskutování odpovědí na otázku «Jaká je tvá identita?») a fotografií (výběr 60 fotografií získaných především z online učební databáze Scran, která nabízí přístup ke sbírkám muzeí, knihoven a archivů, přičemž respondenti měli za úkol vybrat fotografie, které dle jejich názoru reprezentují Skotsko a svou volbu měli zdůvodnit). Získaná data byla analyzována a kódována za pomocí předem vytvořených, $v$ literatuře identifikovaných témat i témat, které odhalily probíhající diskuze. Reflektována byla především témata, která se zaměřovala na rozlišování mezi minulostí a současností, kulturním dědictvím, zvyky a kulturou a to $\mathrm{z}$ hlediska diskuze o kulturních rozdílech, spolu s dalšími tématy jako je politika, etnicita, jazyk, místo původu (rodná země), autenticita a kulturní odlišnost. Výzkum se zaměřil také na analýzu narativních strategií, které mladí lidé využívají za účelem potvrzení, zprostředkování nebo odmítnutí konceptu „skotstvi““ jako kulturně rozmanitého fenoménu, respektive multikulturně konceptualizovaného jevu.

Výzkum odhalil ve výpovědích respondentů několik základních témat. Jednou z kategorií, založenou na diskurzu rozmanitosti, bylo vyjádření přesvědčení respondentů, že rozmanitost přinesla skotské společnosti řadu benefitů. Respondenti spadající do této kategorie často vyjadřovali názor, že lidé by měli mít otevřenou mysl a měli by tolerovat různorodost, přičemž tyto charakteristiky předkládali jako součást své vlastní identity a povahy. Dle autorky výzkumu tak respondenti činili často $\mathrm{v}$ rámci hraní role (v Goffmanově pojetí) za cílem budování dobrého obrazu o sobě samém. Zároveň výzkum ukázal, že návštěvníci v muzejních objektech hledali spíše významy, které potvrzovaly jejich dosavadní pojetí identity, než že by si výrazně všímali těch prvků, které jejich dosavadní pojetí nabourávaly či narušovaly jejich stávající pohled na svět. To se odráželo napřr. v tom, že si respondenti spadající do této kategorie všímali především fotografií, které dle jejich pojetí reprezentovaly multikulturalitu země a právě tyto fotografie pak vybírali jako důležité snímky reprezentující skotskou národní identitu.

Druhou kategorií narativů byl diskurs vyhýbání se/reflexe. Do této kategorie patřili respondenti, kteří naopak obrazy prezentující etnickou a náboženskou rozmanitost Skotska odmítali. Ve svých výpovědích často mnozí z nich volili strategie, které jim umožňovaly odmítnout pluralitní definice národnosti a zároveň se vyhnout možnému osočení z předsudků. Činili tak např́klad odkazováním na to, co bylo řečeno (jinými) ve viděném filmu a vyhýbáním se sdělení vlastního názoru. Jiní respondenti naopak vyjadřovali svůj nesouhlas s předkládanými narativy otevřeně. Dle těchto respondentů prezentace kulturní rozmanitosti v muzeu ohrožovala pojetí národní identity a proto tito respondenti alternativní muzejní narativy odmítali, byt jim byli schopni porozumět. Výsledky výzkumu tak ukázaly, že návštěvníci mohou porozumět $\mathrm{v}$ muzeu předkládanému alternativnímu názoru, aniž by tento proces porozumění a vidění jiného názoru ovlivnil podobu jejich doposud osvojeného postoje, nějak jej modifikoval či zaujatý názor vyvracel.

Pokud bychom chtěli výsledky výzkumu shrnout, musíme nejprve říci, že př́stup založený na mikro-úrovni neumožňuje zobecnit výsledky na celou populaci, což si autorka výzkumu plně uvědomovala. I přes nemožnost zobecnění ale dle Lloyd výzkum přinesl celou řadu zajímavých a pro muzea a jejich činnost i politiku využitelných zjištění a otevřel řadu témat, kterým by muzea měla věnovat pozornost. Tak např. se ukázalo, že jedinci, kteří zdůrazňují význam historic- kých definic národnosti, budou $\mathrm{k}$ muzeem předkládaným tématům migrace a multikulturality spíše kritičtí a budou více pochybovat o jejich důvěryhodnosti i přínosu pro skotskou národní identitu, spíše, než že by si muzeem předkládané alternativní informace a postoje osvojili. Navíc běžnou představou respondentů bylo, že by skotská muzea měla prezentovat především významné historické představitele Skotska a vědecké novinky, spíše než předkládat narativy o kulturní odlišnosti, které nejsou pro Skotsko a jeho obraz natolik typické. Tato témata byla proto respondenty v rámci národního muzea často zpochybňována a odmítána. Narativy týkající se kulturní diverzity, které podle velké části respondentů prezentovaly ve Skotsku přítomný multikulturalismus, bývaly vnímány jako hodící se spíše do jiných typů muzeí, která se sama o sobě na téma kulturní rozmanitosti zaměřují více, než to ze své podstaty činí muzeum národní. Zároveň se ukázalo, že ty typy muzeí, které se snaží předkládat alternativní témata, postoje a názory budou spíše navštěvovány lidmi, kteří tato témata i postoje sdílejí, než lidmi s opačnými názory, na které se ale primárně tato muzea snaží působit. Zůstává tedy předpokladem, že příběhy o národní identitě, které muzea konstruují, mohou mít jen velmi malý a omezený vliv na návštěvníkovo pojetí národní identity a tento vliv je o to menší, když návštěvníci vnímají předkládané konstrukce jako vytvořené a prezentované „shora“ a tak i jako odtržené od jejich každodenní osobní zkušenosti.

\section{SHRNUTÍ VÝZKUMNÝCH STUDIÍ}

Závěrem shrňme, jak byly analyzované studie metodologicky vystavěny, jak poznatkově přispěly k otázce výzkumu národní identity v muzeu a k jakým zjištěním v kon- 
textu tématu národní identity samy dospěly.

\section{Metodologie výzkumů}

Předkládané výzkumné studie byly kvalitativního charakteru, což odpovídá současnému muzejně-výzkumnému diskurzu. Kvalitativní design studií se promítl především do metod sběru dat, které se zakládaly na metodách dotazování se respondentů, i do následné metodologie analýzy získaných dat, které se zajímaly o zisk hlubších informací o konkrétních zkoumaných jevech. V první studii ${ }^{51}$ šlo o použití nestandardizovaných rozhovorů a jejich následnou analýzu za pomocí kvalitativní obsahové analýzy. Rozhovory byly prováděny s pracovníky muzea (s ředitelem, kurátory a designéry výstav). Specifikem tohoto výzkumu je právě to, že se $\mathrm{v}$ rámci sběru dat zaměřuje na výpovědi zaměstnanců muzea, nikoli jeho návštěvníků. Tento postup si kladl za cíl zjistit, jaký postoj vybraná muzea zaujímají ke konceptu národní identity, jakým způsobem ji konstruují a prezentují (zda nabízejí homogenní či partikulární pojetí národní identity) a jakými faktory jsou v tomto procesu prezentace národní identity ovlivňována a omezována. V centru výzkumné pozornosti tak byl muzejní diskurz národní identity, který je konstruován a praktikován zaměstnanci muzea pod vlivem řady společenských faktorů, které na muzeum působí, jako jsou např. politické cíle zřizovatelů muzea, tematická zaměřenost muzea, finanční prostředky apod.

Druhý výzkum ${ }^{52}$ využil metodu polostrukturovaných rozhovorů a ohniskových skupin s responden-

51 Nation and National Museums, a Contested Relationship: An Analysis of US. National Museums in the Twenty-first Century. Curator: The Museum Journal, 2014, roč. 57, č. 1, s. 97-106.

52 Voices from the Museum: Qualitative Research Conducted in Europe's National Museums. EuNaMus Report No 6. (Linköping University Interdisciplinary Studies 17). Sweden: Linköping University Electronic Press, 2012. ty, kterými byli nikoli pracovníci muzea, jako tomu bylo u předchozí studie, nýbrž jeho návštěvníci. Kvalitativní výzkumný design tuto studii neomezil z hlediska výzkumného vzorku, který měl $\mathrm{v}$ tomto př́ipadě nejen rozsah 166 respondentů, ale také mezinárodní charakter. Cílem výzkumu bylo zjistit především to, jak se muzea podílejí na procesu konstrukce národní identity svých návštěvníků a jak tito návštěvníci národní identitu vnímají. Pozornost tak byla věnována dominantním muzejním narativům, které se na konstrukci a prezentaci národní identity podílejí. Zdrojem informací a analyzovaných dat přitom byli návštěvníci muzea, kteří sami měli vyhodnotit, jak na ně muzeum a jím konstruovaná a prezentovaná národní identita působí, jak ji interpretují a sami pojímají. $\mathrm{V}$ tomto ohledu se výzkumníci setkali s problémem nemožnosti porovnávat návštěvníkovo pojetí národní identity $\mathrm{v}$ čase před a po návštěvě muzea, která by v dosavadním pojetí národní identity návštěvníků mohla hrát nějakou roli a podílet se na změně tohoto pojetí. Jelikož ale výzkumníci neučinili výzkumnou etapu, v níž by zjištovali podobu pojetí národní identity respondentů ještě před samotnou návštěvou muzea, nemohli následně po muzejní návštěvě sebrané rozhovory s touto prvotní kategorií porovnávat a tak zjištovat, jak se pojetí národní identity respondentů po návštěvě muzea změnilo, pokud se vůbec nějak změnilo. Tento problém se výzkumníci rozhodli vyřešit stanovením nové výzkumné otázky, která se tázala, zda muzea nějakým způsobem zpochybnila stávající představu návštěvníka o národní identitě. Stanovením této otázky výzkumníci poukázali na to, že reflektují problém chybějící výzkumné etapy, s jejímiž výsledky by mohli porovnávat získaná data a pomocí nové výzkumné otázky se pokusili se situací vyrovnat, což se jim poměrně dobře podařilo. Přesto však mohl být výzkum zahrnující také výzkumnou etapu zjištující obecné pojetí národní identity respondentů bohatší na zjištěná data a výzkumné závěry a výzkumníkům mohl přinést hlubší porozumění zkoumané problematice.

Co je na druhou stranu kladem výzkumu, je jeho uvědomění si důležitosti návštěvníkových dřívějších znalostí a zkušeností, které se následně promítají do procesu konstrukce národní identity v muzeu. Byt̉ autoři sami implicitně nezmiňují konstruktivistické teorie učení, je možné pozorovat, že se o ně v rámci výzkumného procesu opírají a nepřímo tak zdůrazňují jejich vliv na proces konstrukce národní identity. Tj. upozorňují na fakt, že ke konstrukci národní identity v muzeu nedochází izolovaně, nýbrž pod vlivem návštěvníkových osobnostních a dalších charakteristik, životních zkušeností a dosavadních postojů.

Třetí výzkumná studie ${ }^{53}$ se stejně jako ta druhá opírala o metodu polostrukturovaných rozhovorů a ohniskových skupin prováděných s návštěvníky muzea za pomocí využití narativního výzkumného př́stupu. Studie si kladla za cíl zjistit, jakou úlohu hrají muzejní artefakty $\mathrm{v}$ pojetí národní identity respondentů, a výzkumná pozornost se zaměřila především na to, jak respondenti vnímají muzeem prezentovanou homogenitu či pluralitu národních identit. Zajímavostí studie je, že do svého výzkumného designu zařadila techniky vizuální stimulace (film, fotografie), které jsou v rámci zkoumání muzejních narativů užitečnou metodologickou pomůckou, kolem které se může odehrávat s respondenty prováděný rozhovor.

\footnotetext{
53 LLOYD, Katherine. Beyond the rhetoric of an "inclusive national identity": Understanding the potential impact of Scottish museums on public attitudes to issues of identity, citizenship and belonging in an age of migrations. Cultural Trends, 2014, roč. 23 , č. 3 , s. 148-158.
} 


\section{Výzkumná zjištění}

Zajímavostí je, že výzkumy ${ }^{54}$ poukazovaly na trvající důležitost a význam, jenž s sebou pro respondenty i v dnešní době stále nese koncept národní identity. Od něj dle výzkumných zjištění respondenti studií stále odvozují svou osobní a sociální identitu jako takovou. Pojem národa tak stále zůstává důležitou kategorií (nejen) muzejního prostředí. Dnešní muzea se však více než jindy potýkají s problémem prezentace národní identity, která může být prezentována jako homogenní či jako partikulární kvalita. Situace konstrukce národní identity v muzeích se proto různí a některá muzea prezentují spíše jednu dominantní národní identitu, jiná muzea se naopak pokouší vytvářet prostor pro prezentování mnoha partikulárních národních identit. To s sebou ale nese celou řadu obtíží, nebot jak se ukazuje, ne všichni návštěvníci či zřizovatelé muzea o tuto prezentaci plurality v muzeu stojí. ${ }^{55}$ Obvykle je pak situace nejsložitější pro nejstarší národní muzea, od nichž veřejnost mnohdy očekává, že budou prezentovat jednotnou národní identitu, která bude mít spíše tradiční a homogenní podobu. Proto je pro tato muzea mnohem těžší prezentovat vícero alternativních pojetí reality, nabízet rozmanité a mnohoznačné narativy, předkládat pluralitní identity a vyvolávat diskuzi, než je tomu u jiných typů muzeí.

\footnotetext{
54 Srov. Nation and National Museums, a Contested Relationship: An Analysis of US. National Museums in the Twenty-first Century. Curator: The Museum Journal, 2014, roč. 57, č. 1, s. 97-106; Voices from the Museum: Qualitative Research Conducted in Europe's National Museums. EuNaMus Report No 6. (Linköping University Interdisciplinary Studies 17). Sweden: Linköping University Electronic Press, 2012.

55 Srov. Nation and National Museums, a Contested Relationship: An Analysis of US. National Museums in the Twenty-first Century. Curator: The Museum Journal, 2014, roč. 57, č. 1, s. 97-106; LLOYD, Katherine. Beyond the rhetoric of an "inclusive national identity": Understanding the potential impact of Scottish museums on public attitudes to issues of identity, citizenship and belonging in an age of migrations. Cultural Trends, 2014, roč. 23, č. 3, s. 148-158.
}

Národní muzea přitom byla respondenty ${ }^{56}$ obvykle chápána jako autoritativní a důvěryhodná místa prezentující národní identitu založenou především na historii dané země a jejích tradicích, zvyklostech a kultuře jako takové, tedy i na jazyku, významných osobnostech, kulturních zvláštnostech a hodnotách, nebo vědeckých objevech apod. Muzea jako místa oplývající autoritou pak můžeme chápat jako místa spojená s mocí. Moc muzeí projevující se v možnosti konstruovat narativy prezentující národní identitu byla přitom legitimizována jejich specifickou společenskou rolí, spjatou s uchováváním lidské historie a paměti. Prezentace této historie a paměti byla návštěvníky často chápána jako pravdivá právě díky tomu, že muzea lidé vnímali jako místa oplývající potřebnou historickou znalostí a snahou ji pravdivě prezentovat. Projevuje se zde tedy víra v abstraktní systémy, o které hovoří Giddens. ${ }^{57} \mathrm{~V}$ prostředí muzea tak můžeme předpokládat, že návštěvníci jakožto laici důvěřují ve vědění pracovníků muzea a tvůrců expozice stejně jako důvěřují i jiným expertním systémům, které mohou prezentovat např. lékaři, soudci, bankéri, automechanici, vědci a další odborníci a experti.

Přestože návštěvníci poukazovali na víru $v$ autenticitu a důvěryhodnost muzeem prezentovaných informací, analýza studiî́ ${ }^{58}$ ukázala, že na poje-

\footnotetext{
56 Srov. Voices from the Museum: Qualitative Research Conducted in Europe's National Museums. EuNaMus Report No 6. (Linköping University Interdisciplinary Studies 17). Sweden: Linköping University Electronic Press, 2012; LLOYD, Katherine. Beyond the rhetoric of an "inclusive national identity": Understanding the potential impact of Scottish museums on public attitudes to issues of identity, citizenship and belonging in an age of migrations. Cultural Trends, 2014, roč. 23, č. 3, s. $148-158$

57 GIDDENS, Anthony. Důsledky modernity. Praha: Sociologické nakladatelství, 2003.

58 Srov. Voices from the Museum: Qualitative Research Conducted in Europe's National Museums. EuNaMus Report No 6. (Linköping University Interdisciplinary Studies 17). Sweden: Linköping University Electronic Press, 2012; LLOYD, Katherine. Beyond the rhetoric of an "inclusive national identity": Understanding the potential impact of Scottish
}

tí národní identity návštěvníků mají muzea jen omezený vliv. Návštěvníci jsou totiž aktivními participanty na procesu muzejní návštěvy a s ní pojící se konstrukce národní identity (jak na to ostatně upozorňují konstruktivistické teorie učení v kontextu osvojování si jakéhokoli typu informací a postojů $\mathrm{v}$ prostředí školy či muzea). Do interpretace předkládaných narativů týkajících se národní identity návštěvníci vkládají své dosavadní zkušenosti, postoje a interpretační rámce, stejně jako se na nich podílejí také jejich osobnostní a další charakteristiky, jakými mohou být věk, příslušnost $\mathrm{k}$ většinové či menšinové národnosti apod. Tento fakt by si přitom výzkumníci zajímající se o proces konstrukce národní identity v muzeu měli uvědomit a zahrnout jej do svého bádání již na samotném začátku chystání výzkumu. Vliv konstruktivistických teorií učení se do podoby výzkumu pak může promítnout třeba tak, že pro sběr dat a jejich následnou analýzu budou využívány právě kvalitativní výzkumné metody, které dávají prostor pro vyjádření se respondentů a orientují se na detailní prozkoumání jejich postojů a názorů a spolu $s$ tím se zaměřují i na pochopení procesů konstrukce národní identity, které se odehrávají v myslích návštěvníků.

Zajímavým zjištěním, na který upozornil výzkum Lloyd, ${ }^{59}$ je, že návštěvníci si v rámci expozic často vybírají právě ty prvky, které jejich dosavadní názory a postoje potvrzují, spíše než že by je vyvracely nebo jim nabízely alternativní pohled. Ten bývá návštěvníky sice rozpoznán, avšak spíše než že by se radikálním způsobem podílel

museums on public attitudes to issues of identity, citizenship and belonging in an age of migrations. Cultural Trends, 2014, roč. 23, č. 3, s. 148-158.

59 LLOYD, Katherine. Beyond the rhetoric of an "inclusive national identity": Understanding the potential impact of Scottish museums on public attitudes to issues of identity, citizenship and belonging in an age of migrations. Cultural Trends, 2014, roč. 23 , č. 3 , s. 148-158. 
na restrukturalizaci dosavadního interpretačního rámce, bývá tento alternativní model často zpochybňován nebo zcela odmítán. Pro muzea tak vyvstává obtížná situace, v rámci které hledají odpověd' na otázku, jak reprezentovat pluralitní globalizující se společnost tak, aby tyto reprezentace byly návštěvníky nejen pochopeny, ale také přijímány a uznány za vhodné a legitimní. Pro výzkumníka se naopak opět objevuje problematika zapojení konstruktivistických teorií učení do procesu výzkumu a jeho designu. Ukazuje se totiž, že dřivější návštěvníkovy zkušenosti a postoje nejenže ovlivňují způsob interpretace muzeem předkládaných informací a narativů, ale mohou zásadním způsobem ovlivnit také jejich samotný výběr. Tedy nejen to, jak budou informace a narativy interpretovány, ale i to, kterým $\mathrm{z}$ nich bude vůbec věnována návštěvníkova pozornost. I tato situace pak poukazuje na to, že moc muzeí konstruovat národní identitu a předávat ji svým návštěvníkům je jen omezená. Neodehrává se navíc odtržena od návštěvníkovy aktivity a životní zkušenosti, stejně jako ani od celého kontextu v muzeu prožívané zkušenosti a sociokulturních podmínek, v nichž muzejní expozice vzniká.

\section{ZÁVĚR}

Národní identita je významným společenským fenoménem, jehož výzkumem se humanitní vědy, včetně věd muzeologických a muzejněpedagogických, zabývají. Výzkum muzeí, muzejního publika a s muzeem souvisejícího tématu národní identity může probíhat různými způsoby od výzkumu kvantitativního, přes kvalitativní až po smíšený design výzkumu. Pro oblast výzkumu národní identity v muzeu je přitom vhodné používat právě kvalitativní metodologii (ať už jako samostatný metodologický nástroj, nebo doplnit kvantitativní výzkum o kvalitativní rozměr), nebot právě s pomocí kvalitativní metodologie je možné získat hlubší vhled do zkoumané problematiky. A právě pochopení zkoumaného jevu v jeho hlubších souvislostech je pro výzkum týkající se prezentace a konstrukce národní identity v muzeu a jejího vnímání z pozice návštěvníkù stěžejní.

Kvalitativní metodologie byla přitom základem také prredkládaných výzkumných studií, které poukázaly na důležitost muzeí jakožto společenských institucí, v jejichž rámci probíhá proces konstrukce a prezentace národní identity a jejího případného osvojování si návštěvníky. To vše se přitom děje s ohledem na návštěvníkovy osobnostní charakteristiky a dosavadní zkušenosti a postoje. Proto je vhodné zkoumat národní identitu v muzeu a její vliv na návštěvníky $\mathrm{v}$ kontextu uvědomění si důležitosti konstruktivistických teorií učení, které jedincovu osobnost, dosavadní zkušenosti a znalosti v procesu konstrukce významů a pochopení předkládaných informací a narativů zohledňují.

Výzkumy také naznačily, že národní muzea sehrávají specifickou roli $\mathrm{v}$ procesu prezentace a konstrukce národní identity i díky tomu, že jsou návštěvníky vnímána jako pravdou a autoritou oplývající místa. Ukazuje se tak vztah tzv. kritických teorií muzea k procesu výzkumu konstrukce národní identity v muzeu. Tyto kritické teorie upozorňují právě na schopnost muzeí selektovat či manipulovat vybrané narativy týkající se národní identity a s nimi pojící se informace. I tuto teoretickou rovinu by si pak výzkumníci, spolu s konstruktivistickými teoriemi učení, měli uvědomit a do svého výzkumu ji zahrnout. To v praxi může vypadat např. tak, že se budou výzkumníci zabývat jak samotným muzeem a jeho cíli vztahujícími se k prezentaci národní identity, jeho dílčími narativy a muzejními artefakty, tak i tím, jak kon- krétní návštěvníci expozice vnímají a hodnotí muzeem prezentovanou národní identitu a jaké informace vztahující se $\mathrm{k}$ tématu národní identity si z muzea odnášejí a jak se muzejní návštěva promítla do jejich pojetí národní identity jako takové. Díky tomu může dojít $\mathrm{k}$ detailnějšímu a přesnějšímu zkoumání národní identity a její konstrukce i prezentace $\mathrm{v}$ prostředí muzea.

\section{SEZNAM LITERATURY}

CAREY, Sean. Undivided Loyalties. Is National Identity an Obstacle to European Integration? European Union Politics, 2002, roč. 3, č. 4, s. 387-413.

DISMAN, Miroslav. Jak se vyrábí sociologická znalost: Příručka pro uživatele. Praha: Karolinum, 2000. ISBN 978-80-246-0139-7.

FALK, John H., Lynn D. DIERKING a Marianna ADAMS. Living in a Learning Society: Museums and Free-choice Learning. In MACDONALD, Sharon (ed.). A Companion to Museum Studies. Malden: Wiley-Blackwell, 2006, s. 323-339. ISBN 978-1-4051-0839-3.

GELLNER, Arnošt. Národy a nacionalismus. Praha: Hříbal, 1993. ISBN 80-901381-1-X.

GELLNER, Ernest. Pluh, meč a kniha: struktura lidských dějin. Brno: Centrum pro studium demokracie a kultury, 2001. ISBN 978-808-5959-871.

GELLNER, Ernest. Nacionalismus. Brno: Centrum pro studium demokracie a kultury, 2003. ISBN 978-80-7325-023-2.

GIDDENS, Anthony. Důsledky modernity. Praha: Sociologické nakladatelství, 2003. ISBN 80-86429-15-6.

HEIN, George E. Evaluating Teaching and Learning in Museums. In HOOPERGREENHILL, Eilean (ed.). Museum, Media, Message. London: Routledge, 1995, s. 189-203.

HEIN, George E. Is Meaning Making Constructivism? Is Constructivism Meaning Making? The Exhibitionist, 1999, roč. 18, č. 2 , s. $15-18$.

HEIN, George E. The Challenge and Significance of Constructivism. In Hands-On! Europe Conference. London, 2001, s. 35-42.

HENDL, Jan. Kvalitativní výzkum. Praha: Portál, 2005. ISBN 80-7367-040-2.

HOBSBAWM, Eric J. Národy a nacionalismus od roku 1780: program, mýtus, realita. Brno: Centrum pro studium demokracie a kultury, 2000. ISBN 80-85959-55-0. 
HOOPER-GREENHILL, Eilean. Audiences - A Curatorial Dilemma. In PEARCE, Susan. Art in Museums. London: Athlone Press, 1995, s. 143-163. ISBN 978-0-485-90005-7.

HOOPER-GREENHILL, Eilean. Studying Visitors. In MACDONALD, Sharon (ed.). A Companion to Museum Studies. Malden: Wiley-Blackwell, 2006, s. 362-376. ISBN 978-1-4051-0839-3.

HROCH, Miroslav. Pohledy na národ a nacionalismus: čítanka textů. Praha: Sociologické nakladatelství, 2003. ISBN 80 -86429-20-2.

HROCH, Miroslav. Národy nejsou dílem náhody. Praha: Sociologické nakladatelství, 2009. ISBN 978-80-7419-010-0.

JAGOŠOVÁ, Lucie, Vladimír JU゚VA a Lenka MRÁZOVÁ. Muzejní pedagogika: metodologické a didaktické aspekty muzejní edukace. Brno: Paido, 2010. ISBN 978-80-7315-207-9.

JANDOUREK, Jan. Sociologický slovník. Praha: Portál, 2001. ISBN 80-7178-535-0.

KESNER, Ladislav. Marketing a management muzeí a památek. Praha: Grada, 2005. ISBN 978-80-247-6364-4.

KREUZZIEGER, Milan. Flexibilní identita a projekt kosmopolitního muzea. Politologická revue, 2008, č. 1, s. 87-97. ISSN 1211-0353.

LAVI, Liron. Making Time for National Identity: Theoretical Concept and Empirical Glance on the Temporal Performance of National Identity. Nations and Nationalism, 2013, roč. 19, č. 4, s. 696-714. ISSN 1469-8129.

LLOYD, Katherine. Beyond the rhetoric of an "inclusive national identity": Understanding the potential impact of Scottish museums on public attitudes to issues of identity, citizenship and belonging in an age of migrations. Cultural Trends, 2014, roč. 23 , č. 3 , s. 148-158. ISSN 0954 $-8963$.

MAŘÍKOVÁ, Hana, Miroslav PETRUSEK a Alena VODÁKOVÁ et al. Velký sociologický slovník. Praha: Karolinum, 1996. ISBN 80-7184-164-1.

NAVARRO, Oscar. History and education as bases for museum legitimacy in latin american museums: some comments for a discussion from a critical muzeology point of view. Museologica Brunensia, 2012, roč. 1, č. 1, s. 28-33.

Nation and National Museums, a Contested Relationship: An Analysis of US. National Museums in the Twenty-first Century. Curator: The Museum Journal, 2014, roč. 57, č. 1, s. 97-106. ISSN 0011-3069.

RAGIN, Charles. Constructing Social Research. London: Pine Forge Press, 1994. ISBN 978-0-8039-9021-0.
SCHUSTER, J. The Public Interest in the Art Museum's Public. In PEARCE, Susan. Art in Museums. London: Athlone Press, 1995, s. 109-142. ISBN 978-0-485-90005-7.

SMITH, Anthony D. National identity and vernacular mobilisation in Europe. Nations and Nationalism. 2011, roč. 17, č. 2, s. 223-256. ISSN 1469-8129.

ŠOBÁŇOVÁ, Petra. Kritické teorie muzea - podnět k reflexi. Muzeum: Muzejní a vlastivědná práce, 2012 , roč. 50 , č. 2 , s. 26-38. ISSN 1803-0386.

ŠOBÁŇOVÁ, Petra. Muzejní expozice jako edukační médium 1. díl: Př́stupy $k$ tvorbě expozic a jejich inovace. Olomouc: Univerzita Palackého v Olomouci, 2014. ISBN 978-80-244-4394-2.

ŠVAŘíČEK, Roman a Klára ŠEĎOVÁ. Kvalitativní výzkum $v$ pedagogických vědách. Praha: Portál, 2007. ISBN 978-80-262-0644-6.

VAN WYK, Anelle. The Unreconciled Ritual: Identity and Politics at the Museum [online]. Netherlands: Humanity in Action, 2000 [cit. 2014-02-12]. Dostupné z www: <http://www.humanityinaction.org/ knowledgebase/302-the-unreconciled-ritual-identity-and-politics-at-the-museum.

Voices from the Museum: Qualitative Research Conducted in Europe's National Museums. EuNaMus Report No 6. (Linköping University Interdisciplinary Studies 17). Sweden: Linköping University Electronic Press, 2012.

WEST, Shearer. The Devaluation of ,Cultura Capital': Post-Modern Democracy and the Art Blockbuster. In PEARCE, Susan. Art in Museums. London: Athlone Press, 1995, s. 74-93. ISBN 978-0-485-90005-7.

WORTS, Douglas. Extending the Frame: Forging a New Partnership with the Public. In PEARCE, Susan. Art in Museums. London: Athlone Press, 1995, s. 164-191. ISBN 978-0-485-90005-7.

\section{VERONIKA KOLAŘíKOVÁ}

Katedra sociální pedagogiky,

Pedagogická fakulta Masarykovy univerzity, Brno, Česká republika kolarikova.veronika@mail.muni.cz

Veronika Kolaříková je absolventkou magisterských studií oboru sociologie na Fakultě sociálních studií Masarykovy univerzity a oboru sociální pedagogika na Pedagogické fakultě Masarykovy univerzity. V současnosti se její odborný zájem orientuje především na problematiku muzejní edukace $s$ užším zaměřením na tematiku národní identity a její konstrukce.

Veronika Kolař́ḱková completed her master's degree in sociology at the Faculty of Social Studies at Masaryk University and a master's degree in social education at the Faculty of Education, Masaryk University. Currently her research interests are mainly focused on issues of museum education with a narrower focus on the topic of national identity and its construction. 